NBSIR 79-1594R

\title{
Propagation of Urban Construction Site Noise Along Street Corridors
}

Paul R. Donavan

Acoustical Engineering Division

Center for Mechanical Engineering and Process Technology

National Bureau of Standards

Washington, D.C. 20234

and

J. Craig Wrvill

Office of Noise Abatement and Control U.S. Environmental Protection Agency Washington, D.C. 20460

April 1979

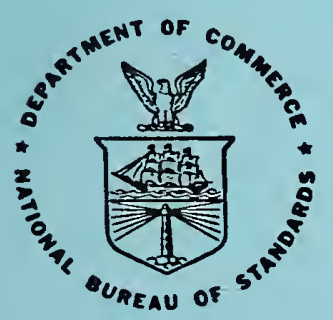

U.S. DEPARTMENT OF COMMERCE

NATIONAL BUREAU OF STANDARDS 


\section{PROPAGATION OF URBAN CONSTRUCTION SITE NOISE ALONG STREET CORRIDORS}

Paul R. Donavan

Acoustical Engineering Division

Center for Mechanical Engineering and Process Technology

National Bureau of Standards

Washington, D.C. 20234

and

J. Craig Wyvill

Office of Noise Abatement and Control U.S. Environmental Protection Agency

Washington, D.C. 20460

April 1979

U.S. DEPARTMENT OF COMMERCE, Juanita M. Kreps, Secretary Jordan J. Baruch, Assistant Secretary for Science and Technology NATIONAL BUREAU OF STANDARDS, Ernest Ambler, Director 


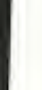

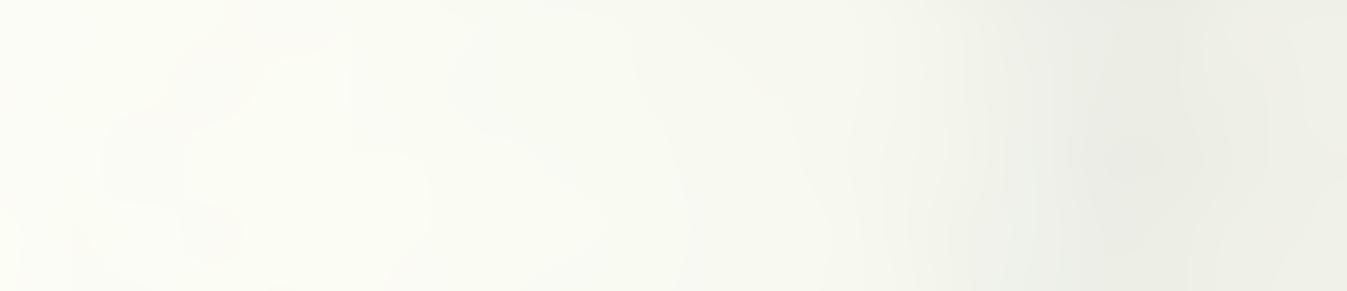


TABLE OF CONTENTS

Page

1. INTRODUCTION . . . . . . . . . . . . . . . 1

2. THE URBAN PROPAGATICN MOLEL . . . . . . . . . . . . 1

3. COMPUTED VALUES OF NOISE ATTENUATION FOR URBAN CONSTRUCTION SITES. - 3

4. SUMMARY OF RESULTS ........................ 7

REFERENCES . . . . . . . . . . . . . . . . . 9

FIGURES .......................... 10

TABLES . . . . . . . . . . . . . . . 29 



\section{INTRODUCTION}

Estimates of the U. S. Environmental. Protection Agency indicate that 103 million Americans experience environmental or community notse from various sources including construction sites. I In the assessment of possible impact of urban construction site noise, it is necessary to have an estimate of the attenuation of sound along the propagation path between the source and the receiver. The attenuation of noise from construction sites in urban areas depends on a number of parameters of which street geometry is the most significant.

The current report addresses construction site nolse propagation along urban street corridors for two different city block configurations, as well as five different construction site orientations relative to a major street intersection. The conceptual propagation model and the computer programs used to estimate urban street corridor sound propagation are presented along with the resultant sound fields determined for the ten configurations studied.

\section{THE URBAN PROPAGATION MODEL}

Urban sound propagation is complicated by many factors including spherical divergence, excess ground and atmospheric attenuation, multiple reflections from bullding surfaces, shielding by buildings, and scattering from the building surfaces. Multiple reflection of sound in city streets creates both local reverberation and the ability of sound to propagate around corners. The shielding effect of buildings constrains the sound radiated by individual sources to propagate along street channels while substantially reducing the sound incident on building surfaces not exposed to the street channel. The scattering of sound from bullding surfaces alters the distribution of sound energy along streets from that predicted from multiple reflection alone and markedly increases the extent by which sound propagates around corners.

In calculations of the contribution of multiple reflection in urban sound propagation, it is useful to employ the geometrical acoustics limit which requires the acoustic wavelength to be much smaller than the typical geometric length scales associated with the propagation problem. In a gross sense, this requirement is usually satisfied in urban areas as the wavelengths of importance to A-weighted sound levels are typically about $1.3 \mathrm{~m}(250 \mathrm{~Hz}$.) to $.17 \mathrm{~m}(2000 \mathrm{~Hz}$.) while street dimensions are generally $15 \mathrm{~m}(50 \mathrm{ft}$ ) or more. With this simplifying assumption, sound propagation due to specular reflection in idealized street channels has been studied by several researchers [2-7]. Good quantitative agreement between the geometric acoustics approximation and acoustic data from physical scale models for smooth, acoustically hard street channels has also been demonstrated $[2,7]$. However, application of this theory to field data of 
sound propagation in actual city streets (e.g., Refs. 8 and 9) 1ndicates that the predicted sound levels (using wall absorption coefficlents consistent with exterior bullding materials) are substantially higher than those measured $[10,11]$.

The discrepancy between fleld data and the specular reflection, geometric acoustics model of urban sound propagation is attributable to the scattering of sound from bullding surfaces. A closer examination of most bullding surfaces reveals that the surfaces often contain many Irregularities formed by doorways, window recesses, and other facade elements. The depth and width of these surface protrusions (and/or recesses) are typically on the order of the acoustic wavelengths of interest. Thus, reflection from actual bullding surfaces is complex and Involves not only a specular component of reflection, but also a scattered component.

The effect of rectangular surface irregularities in modifying the sound distribution in street channels relative to the smooth wall idealization has been demonstrated in studies using acoustic models [5, 7]. These studies revealed that the presence of surface protrusions significantly reduced $(5-10 \mathrm{~dB})$ the sound levels in the street channels at distances of about three or more streets away from the source while the sound levels near the source were slightly increased (1-2 dB) [7]. This trend was found to be more nearly conslstent with the urban sound propagation field data reported.

As part of a study to develop a more sultable urban propagation model which would Inciude surface scattering, an empirical investigation of reflection and scattering from. surfaces with rectangular protrusions was conducted [11]. This investigation determined that the amount of energy specularly reflected from such surfaces was dependent on incident angle. The angularly dependent refiection coefficient (defined as the ratio of the reflected energy to the incident energy) as determined in this study is presented in F1g. 1. In addition to determining an angularly dependent reflection coefficient, the magnitude and angular dependence of the scattered sound was also obtained. For the range of protrusion configurations typically occurring on actual building surfaces, it was further shown that reflected and scattered energy were not significantly dependent on the details of the surface geometry or on irequency for octave bands of noise between 250 and 2000 hertz.

Using the results of this surface reflection investigation, a comprehensive model of urban sound propagation was developed [11]. This model is conceptualiy similar to the geometrical acoustic limit model discussed earlier; however it incorporates angularly dependent reflection from building surfaces and accounts for the energy scattered upon reflection. As part of the development of this model, quantitative agreement was demonstrated between predicted sound level, fleld data, and acoustical model data. The propagarion model was used to develop a number 
of computer programs applicable to propagation cases arising from the comon "grid" pattern" street configuration. These cases include propagation from a single intersection, propagation from one intersection through another, and propagation into the street of the second intersection. For single intersections, the cases of four-way, tee and open (half of a four-way) Intersections were also programmed. With these cases, the sound levels in streets surrounding the street containing a nolse source can be determined, as 1llustrated in Fig. 2. In applying these computer programs it should be noted that the following assumptions are necessary:

- the streets are continuously lined with bulldings

- spacings between adjacent buildings are not greater than $1 / 4$ street widths

- bullding helght is a least 1 street width

- street width is at least 1 order of magnitude greater than the acoustic wavelength of interest

\section{COMPUTED VALUES OF NOISE ATTENUATION FOR URBAN CONSTRUCTION SITES}

The computer programs discussed in Section II were used to estimate noise propagation from construction sites for two different grid patterm urban street geometries. The first case considered was square city blocks which were $180 \mathrm{~m}$ (600 ft) on end. The second case was rectangular city blocks which were $90 \mathrm{~m}(300 \mathrm{ft})$ wide and $180 \mathrm{~m}(600 \mathrm{ft})$ long. For the first case three site locations were used. These sites and the street geometries are presented in Figs. 3 and 4 . The site 1llustrated in Fig. 3 was located in a street channel while those of Fig. 4 were located in an undeveloped (no buildings) block. For the second block configuration case two site locations were used as 1llustrated in Figs. 5 and 6 . The site in Fig. 5 was located at a fourway intersection and the site of Fig. 6 was in a partially developed block such that bulldings were assumed to be present everywhere in the block accept in the $60 \mathrm{~m}(200 \mathrm{ft})$ by $60 \mathrm{~m}$ site.

In applying the urban propagation computer programs to some of the specific construction noise propagation cases of Figs. 3 through 6, some approximations to site and street geometry were required. For the propagation cases of $\mathrm{FIg}$. 3, attenuations in all streets except Street $1 \mathrm{~b}$ could be computed directly. Eecause the existing computer programs do not include propagation through two intersections, it was necessary to determine attenuations in street lb by assuming the intersection of street 2 was not present and that the only intersecting street between the site and the recelver street ( $1 b)$ was the Street 3 intersection. Although the error associated with this approximation can not be quantitatively assessed within the scope of present effort, it is anticipated that this approximation would introduce no more than a 1 or $2 \mathrm{~dB}$ error in the attenuation values in street $1 \mathrm{~b}$ relative to the actual geometric configuration. In order to compute attenuations for the sites of $F 1 g .4$, 
1t was necessary to assume the geometry illustrated in Fig. 7. Although the absence of buildings on either side of the block containing the construction site physically appears quite different from the geometry of FIg. 4, acoustically, the absence of these bulidings will cause only minimal effects in Streets 1 and 3 since, because of their orientation, these buildings do not contribute to the specularly reflected energy in the streets of interest. The assumed geometry of Fig. 7 is anticipated to have no more than about $1 \mathrm{~dB}$ effect on the attenuation values in Streets 1 and 3 relative to the actual site geometries of Fig. 4. An analogous geometry to that of Fig. 7 was used to determine attenuation values for street 2 of FIg. 4 .

For the Case II site and street geometries of Fig. 5, the existing computer programs could be applied directly to determine attenuation values in all streets except Streets $1 \mathrm{c}$ and 3. As was necessary for Street $1 \mathrm{~b}$ of Site A Case $I$, to determine attenuation values in Streets $1 \mathrm{c}$ and 3 of Fig. 5, it was necessary to omit the intervening intersection of Street 2 with Street 1. Again, the effect of this approximation is (should be) minimal. In order to apply the computer programs to the propagation cases of Fig. 6, a similar approximation to that used for Sites B and C of Case I (FIg. 7) was required. However, for this case, since buildings surround the site, the width of the expanded street containing the site is one street width $(23 \mathrm{~m})$ plus the site width $(60 \mathrm{~m})$ rather than two streets plus one block width as was done for Case $I$. This assumed geometry is presented In Fig. 8 as it applies to Streets 1,2 and 3 of Site B, Case II (Fig. 5). As was stated in regard to the corresponding Case $I$ approximation, it is anticipated that the assumed geometry of Fig. 8 will not appreciably effect the calculated attenuation values (no more than about $1 \mathrm{~dB}$ ) due to the lack of contribution from the omitted buildings to the reflected energy in Streets 1, 2, and 3. A geometry analogous to that of Fig. 8 was used to determine attenuation values in Streets 4 and 5 of Site B, Case II (Fig. 6).

Using the site geometries discussed above as needed, noise attenuation values for the various sites for each of the block configurations were computed. The attenuation values for Case $I$ are presented in Tables 1 through 7 for Sites $A, B$, and $C$. These attenuation values are applicable to A-weighted sound level for the construction noise spectral data shown in Figure 9 and to octave band levels for center frequencies from 250 to 2,000 hertz. It will be noted that distance along streets is presented normalized by the street width, or $23 \mathrm{~m}(75 \mathrm{ft})$. This was done since the results are equally applicable to any geometrically similar propagation case ( $1 . e .$, in Case $I$, the values given would be identical to any configuration of square blocks where the ratio of block length to street width was 8 to 1 and the source location was similar). was 8 to 1 and the source location was similar). It will also be noted that the distances in Tables 3, 5, and 6 correspond to the distances along the street from the perpendicular projection of the site location onto the street centerline. The attenuation values of Tables 1 through 7 are also plotted in Figs. 10, 
11, and 12. For these plots, distance is taken to be the distance from the site to the street channel plus the appropriate distance along the channel(s). Using this distance measurement, all the attenuation values for one site could be shown on the same plot. In addition to the urban attenuation values, the ideal free field attenuation rate of $6 \mathrm{~dB}$ per doubling of distance is also indicated in each of Figs. 10, 11, and 12. The location of the intersection openings is also provided in the plots along the distance scale.

The attenuation values for Block Configuration Case II are presented in Tables 8 through 15 . The distance values for Site $B$ were determined in the same manner as those for Case I, Sites B and C. Attenuation versus distance from the site for Case II is plotted in Figures 13 through 16 for Sites $A$ and $B$. In addition to plotted free field attenuation as in Figures 10-12, the attenuation values for Streets 1 and 4 of Site $A$ and Streets 1 and 4 of Site $B$ are plotted for the case of no intervening intersections between the site and the recelver point. These values were included to demonstrate the effect of the intervening intersections on the attenuation values down the respective streets. Examination of these curves in Figs. 13-16 reveals that the effect of the presence of the intersection is to increase the attenuation after the intersection by about 1 to $2 \mathrm{~dB}$ relative to no intervening intersection.

Inspection of the attenuation plots in Figs. 10-12 and Figs. 13-16 leads to several cunclusions relevant to urban propagation of construction noise. On those streets where a line-of-sight is maintained with the site (1.e. Street 1 of Case I, Site A and Streets 1 and 4 of Case II, Site A) the observed sound level is substantially higher than the corresponding free-field sound level. This elevation in level ranges from 2 to $10 \mathrm{~dB}$, depending on distance from the site for these streets. Further, for these streets, the attenuation versus distance values are nearly identical, falling within about 1 to $2 \mathrm{~dB}$ of each other. For those streets in which the site is offset from the street channel (i.e. Streets 1 and 2 for Case $I$, Sites $B$ and $C$, and Streets 1 and 4 for Case II Site B) attenuation versus distance is quite close to attenuation versus distance due to spherical divergence ( $6 \mathrm{~dB} /$ doubling of distance). For these streets, the attenuation values are typically within $3 \mathrm{~dB}$ of the free-field values and within $5 \mathrm{~dB}$ of each other. Finally, for those streets in which the sound propagates inftially down a street channel and then around a corner (1.e. for Case I, Streets 2 and 3 for Site A, Street 3 for Sites B and C; for Case II, Streets 2,3 , and 5 for Sites $A$ and B) the attenuation values increase very rapidly with distance from the site. In most cases this attenuation is between 35 and $40 \mathrm{~dB}$ at distances of less than 20 street widths from the site.

Application of the attenuation values in Tables $1-15$ and in F1gs. $10-16$ can be readily made to determine sound levels in streets due to a particular known source. The steps required to determine these sound levels are: 
1. Calculate the source nolse level at one street width. This is done by subtracting 20 times the logarithm (to the base ten) of the street width divided by the distance for which the free-field source level is spectfled.

2. Determine the normalized distance between the site and the receiver point of interest by dividing the distance by the street width.

3. Using the normalized distance, find the attenuation value corresponding to that distance.

4. Subtract the the attenuation value from the source noise level at one street width to determine the noise level at the point of interest.

As an example of this procedure, suppose it is desired to determine the A-weighted sound level $270 \mathrm{~m}$ (900 ft) from the construction site of Figure 5 in Street 4b. Further, the source is known to have an A-weighted sound level of $82 \mathrm{~dB}$ at $15 \mathrm{~m}$ (50 ft). Following the steps outlined above:

1. The source level at one street width is (expressed in feet) -

$82-20$ LOG $\frac{75 \mathrm{ft}}{50 \mathrm{ft}}=78.5 \mathrm{~dB}$

2. The normalized distance between site and receiver point is (In feet) -

$\frac{900 \mathrm{ft}}{75 \mathrm{ft}}=12$ STREET WIDTHS

3. From Figure 13, the attenuation at 12 street widths for Street $4 \mathrm{~b}$ is about $12 \mathrm{~dB}$

4. The A-weighted sound level at the recelver point is therefore -

$$
78.5-12.0 \simeq 66.5 \mathrm{~dB}
$$

A more direct approach to applying the attenuation values of Figs. 10-16 is simply to adjust the scales of the plots to correspond to the specific case of interest. Assuming the same source noise levels as in the above example, the attenuation values of $\mathrm{Fig} .14$ have been converted to A-welghted sound levels as a function of distance in meters and are presented in Fig. 17. It will be noted the $0 \mathrm{~dB}$ attenuation value at one street width in Fig. 14 corresponds to the A-weighted sound level of $78.5 \mathrm{~dB}$ at $23 \mathrm{~m} \mathrm{in} \mathrm{Fig} .17$ as determined in the previous example.

In addition the propagation cases of Figs. 3-6, an attempt was made to assess the penetration of sound into and through clty blocks due to alleyways in the blocks. An example of the geometry used to attempt such an assessment is given in Fig. 18 for Block Configuration Case II, Site A. It should be noted that the assumed alleyway width is $4.6 \mathrm{~m}$ ( $15 \mathrm{ft}$ ), which is not an order of magnitude greater than the longest acoustic wavelength of Interest, that is, $1.3 \mathrm{~m}$ for 250 hertz. This criteria is only met at 
1000 hertz and above. Therefore, the attenuation values determined by the propagation model can not be confidently applied to 250 and 500 hertz octave-band sound levels or to A-welghted sound levels for the construction noises represented in $\mathrm{Fig}$. 9. In order to have rellable prediction of attenuation values at these frequencies for a $4.6 \mathrm{~m}$ alleyway, the existing propagation model would have to be verified emperically for this case and/or expanded to include the wave properties of sound propagation for this narrow channel width.

Although there are limitations on applying the results, the calculated attenuation values for the alleyway configuration of Fig. 18 are plotted in Fig. 19. Also plotted in Fig. 19 are the attenuation values in Streets 1 and 4 of Site A Case II in the vicinity where the alleyways intersect each respective street. It will be noted that the alleyway attenuation values increase with distance in much the same manner as noted earlier for Streets $2 a, 2 b, 3 a$ and $3 b$ of Site A Case II (Fig. 13). The attenuation values of Fig. 19 indicate, that at least for higher frequencies, penetration of nolse into the block along alleyways may be significant and may result in some noise impact. However, because of limitations of the propagation model in predicting A-weighted attenuation for such narrow channels, no definitive statement about nolse levels along alleyways can be made based on the values of Figure 19.

\section{SUMMARY OF RESULTS}

The urban sound propagation model described in Section II of this report has been applied to several urban configurations to determine attenuation in street corridors near construction sites. The resultant sound level attenuation values presented in Section III can be summarized with several general observations. The first of these observations is that the sound levels and attenuation rate in the street corridors are dependent on the position of the construction site relative to the corridor opening. When the site is located directly in the street opening, the sound level attenuation rate is about $3.5 \mathrm{~dB}$ per doubling of distance along the street. This rate can be approximated by a cylindrical divergence model of channel propagation with some excess attenuation as has been indicated in previous studies $[2,8]$. Further, because this rate is lower than the spherical divergence $(6 \mathrm{~dB} / \mathrm{DD})$ rate that would occur in a idealized open area, the sound level in the street is higher than would be expected in an open area by as much as $10 \mathrm{~dB}$ at distances greater than about ten street widths. When the site is offset from the street corridor opening, the sound level attenuation rate is approximately $6 \mathrm{~dB}$ per doubling of distance along the street and hence more closely approximates the attenuation rate associated with spherical divergence. For these cases, although the attenuation rates are similar, the sound levels in the streets are typically offset slightly higher than would be expected in a free-field environment by as much as $4 \mathrm{~dB}$. 
The second set of observations concerns propagation through and around intervening intersections located between the site and the street of interest. When the propagation path is directly through the intersection, the sound levels in the street past the intersection are only slightly lower ( 1 to $2 \mathrm{~dB}$ ) than would be expected if the intersection were not present. However, when the propagation path includes turning a corner at the intervening intersection, the sound levels in the street around the corner are substantially lower than the sound levels in the street for which the propagation path is directly through the intersection. The difference in sound level between these two streets is initially about 2 to $5 \mathrm{~dB}$ near the intersection decreasing to as much as 15 to $18 \mathrm{~dB}$ before the next intersection. 


\section{REFERENCES}

1. Federal Research, Development and Demonstration Programs in Machinery and Construction Nolse, Federal Interagency Machinery and Construction Nolse Research Panel (Report U.S. Environmental Protection Agency, Office of Noise Abatement and Control, Washington, D.C., February, 1978.)

2. Schlatter, W. R., "Sound Power Measurements in a Semi-Confined Space," M. Sc. Thesis (Massachusetts Institute of Technology, Cambridge, Mass., July, 1971.)

3. Pande, L., "Model Study of Aircraft Nolse Reverberation in a City Street," U. S. Department of Transportation Interim Report, Contract DOT-TSC-93 (Massachusetts Institute of Technology, Department of Mechanfcal Engineering, Cambridge, Mass., April, 1972.)

4. Kinney, W. A., and Pierce, A. D., "Helicoptor Noise Experiments in an Urban Environment," 56, 332-337 (1974).

5. Donavan, P. R. and Lyon, R. H., "A Model Study of the Propagation of Sound from V/STOL Aircraft into Urban Environs," Proc. Second Interagency Symposium on University Research in Transporation Noise, 505-519 (North Carolina State University, Raleigh, N.C., June 1974).

6. Lee, K. P., and Davies, H. G., "Nomogram for Estimating Noise Propagation in Urban Areas," J. Acous. Soc. Amer., ㅌ, 1477-1480 (1975).

7. Donavan, P. R., and Lyon, R. H., "Sound Propagation Near Ground Leve1 In the Vicinity of Street Intersections," Proc. Second Interagency Symposium on University Research in Transportation Noise, 491-504 (North Carolina University, Raleigh, N. C., June 1974.)

8. Wiener, F. M., Malme, C. I., and Gogos, C. M., "Sound Propagation in Urban Areas," J. Acous. Soc. Amer. 37, 738-747 (1965).

9. Delaney, M. E., Copeland, W. C. and Payne, R. C., "Propagation of Traffic No1se in Typical Urban Situations," NPL Acoustics Report, No. AC 54 (October 1971).

10. Lyon, R. H., "Role of Multiple Reflection and Reverberation in Urban Noise Propagation," J. Acous. Soc. Amer., 55, 493-503 ( 1974).

11. Donavan, P. R., "Sound Propagation in Urban Spaces," Sc. D. Thesis (Massachusetts Institute of Technology, Department of Mecharical Engineering, Cambridge, Mass., January 1976.) 


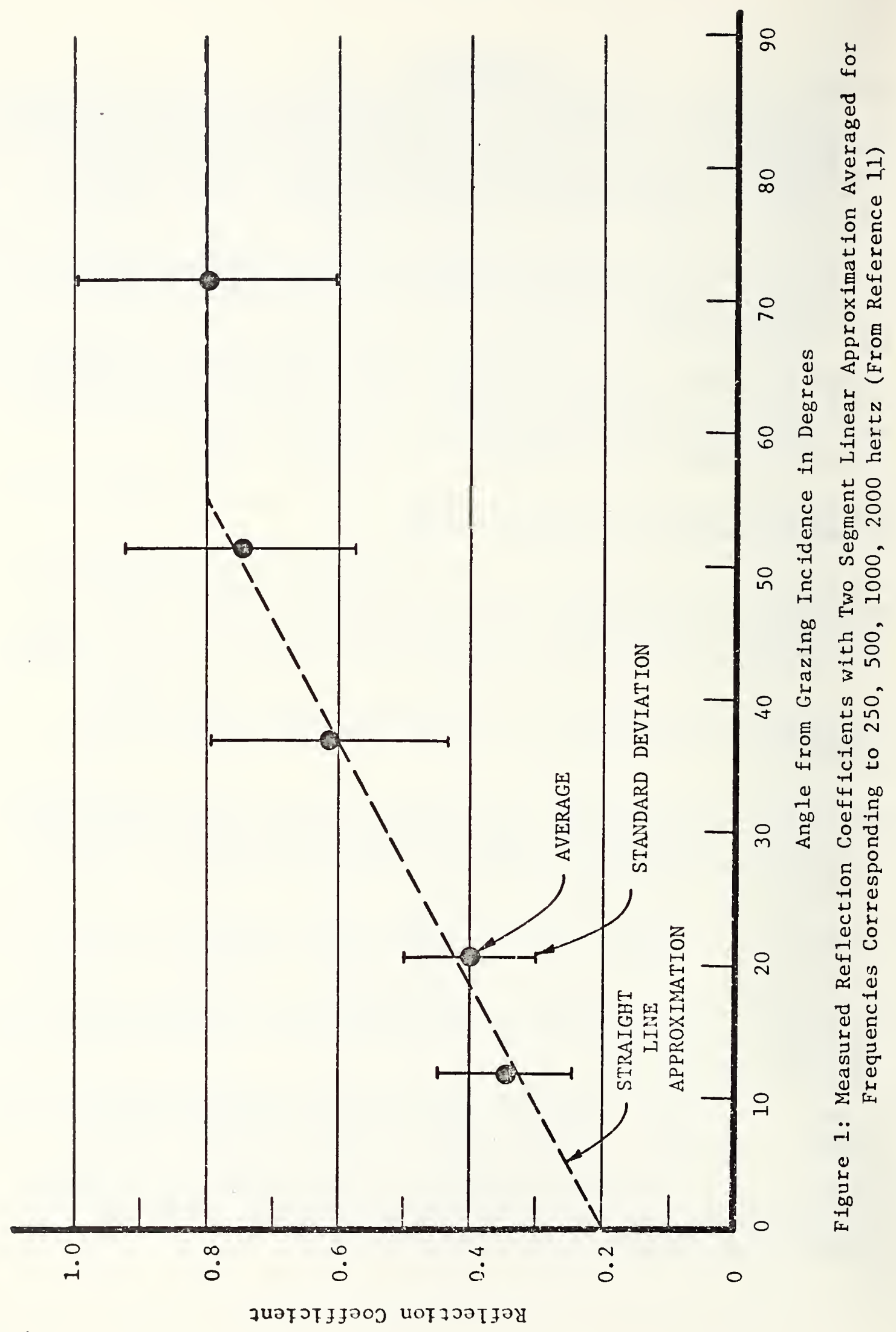




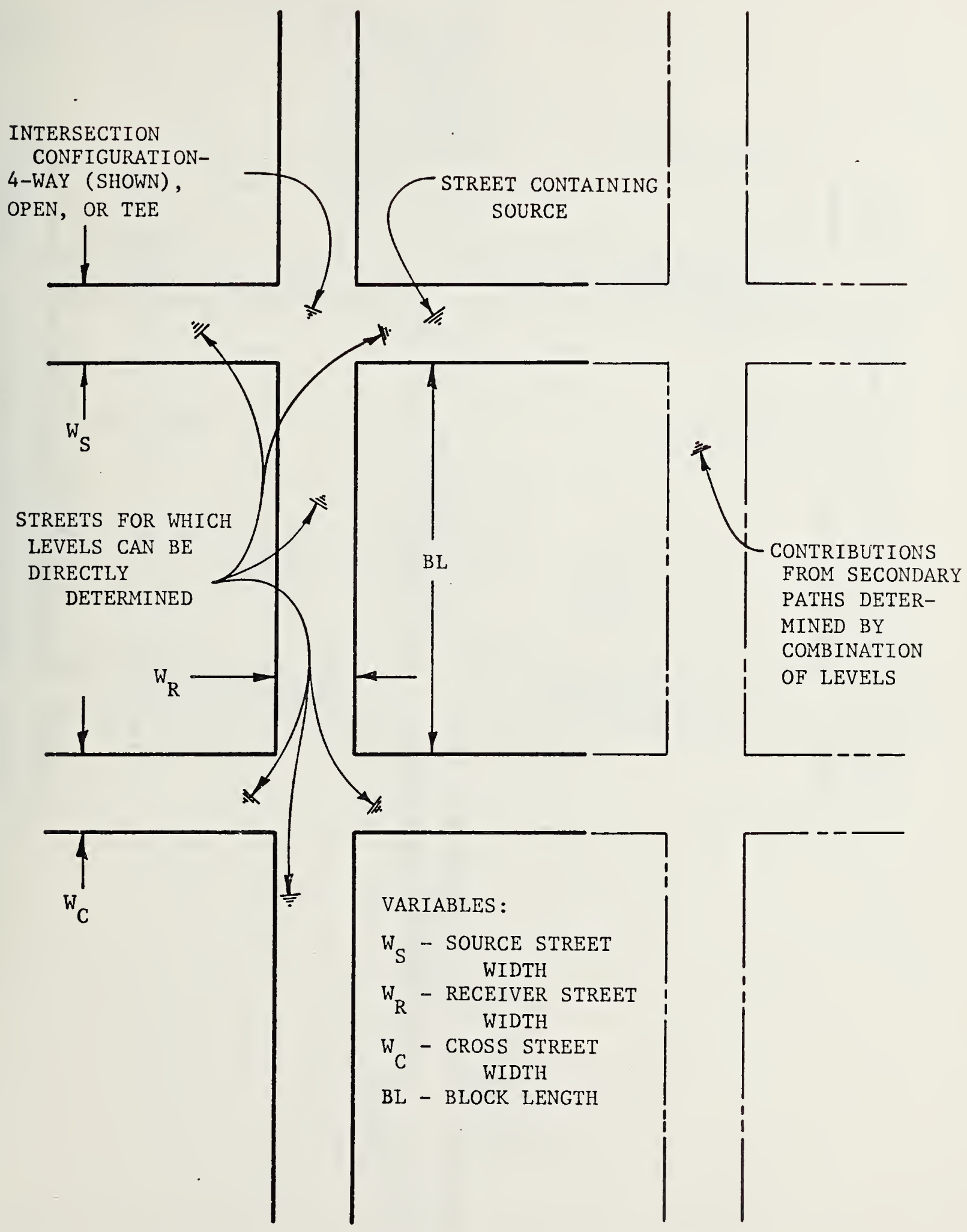

Figure 2: Applicability of Urban Sound Propagation Computer Programs (From Reference 11) 


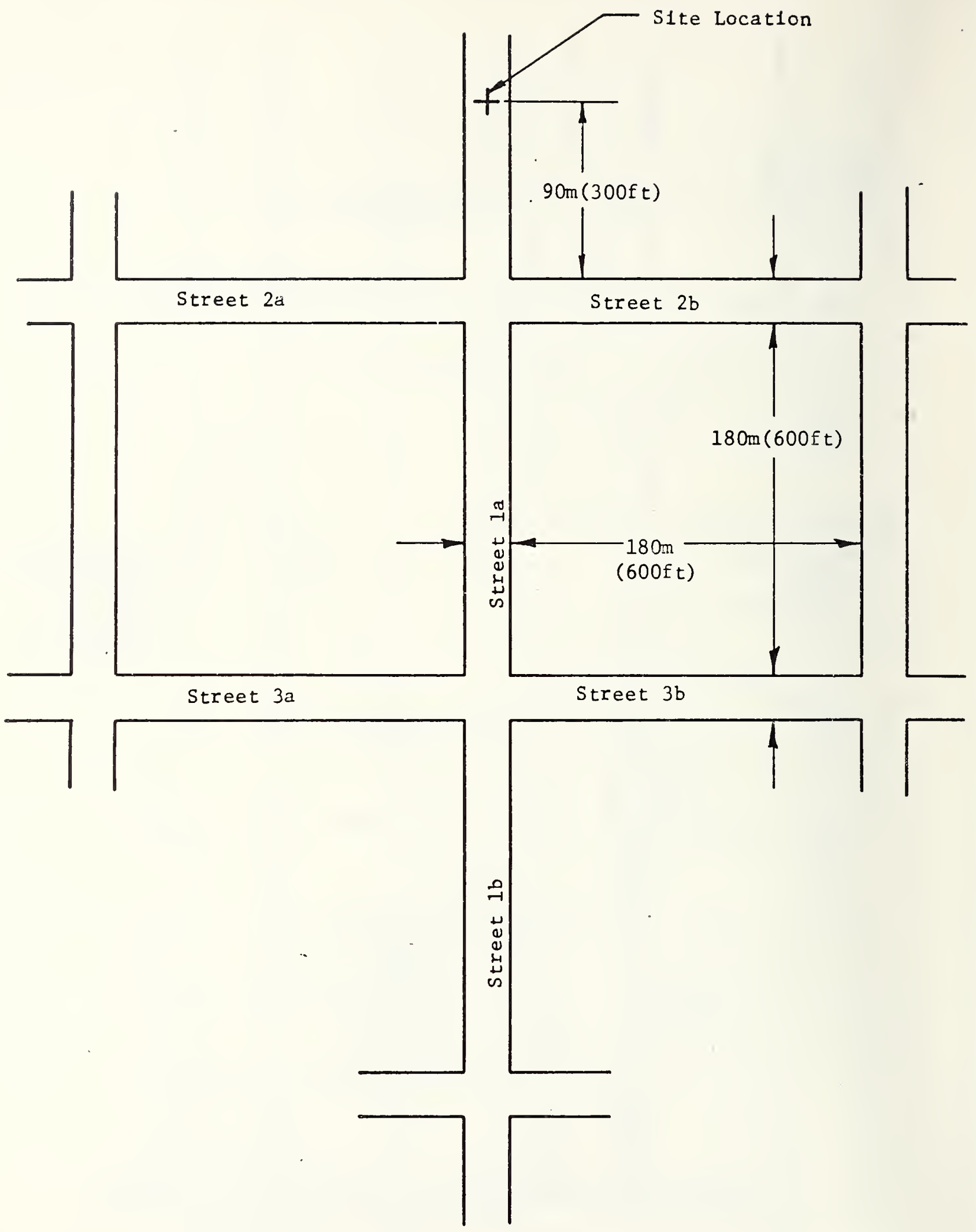

Figure 3 : Geometry and Nomenclature for Block Configuration Case I, Site A. 


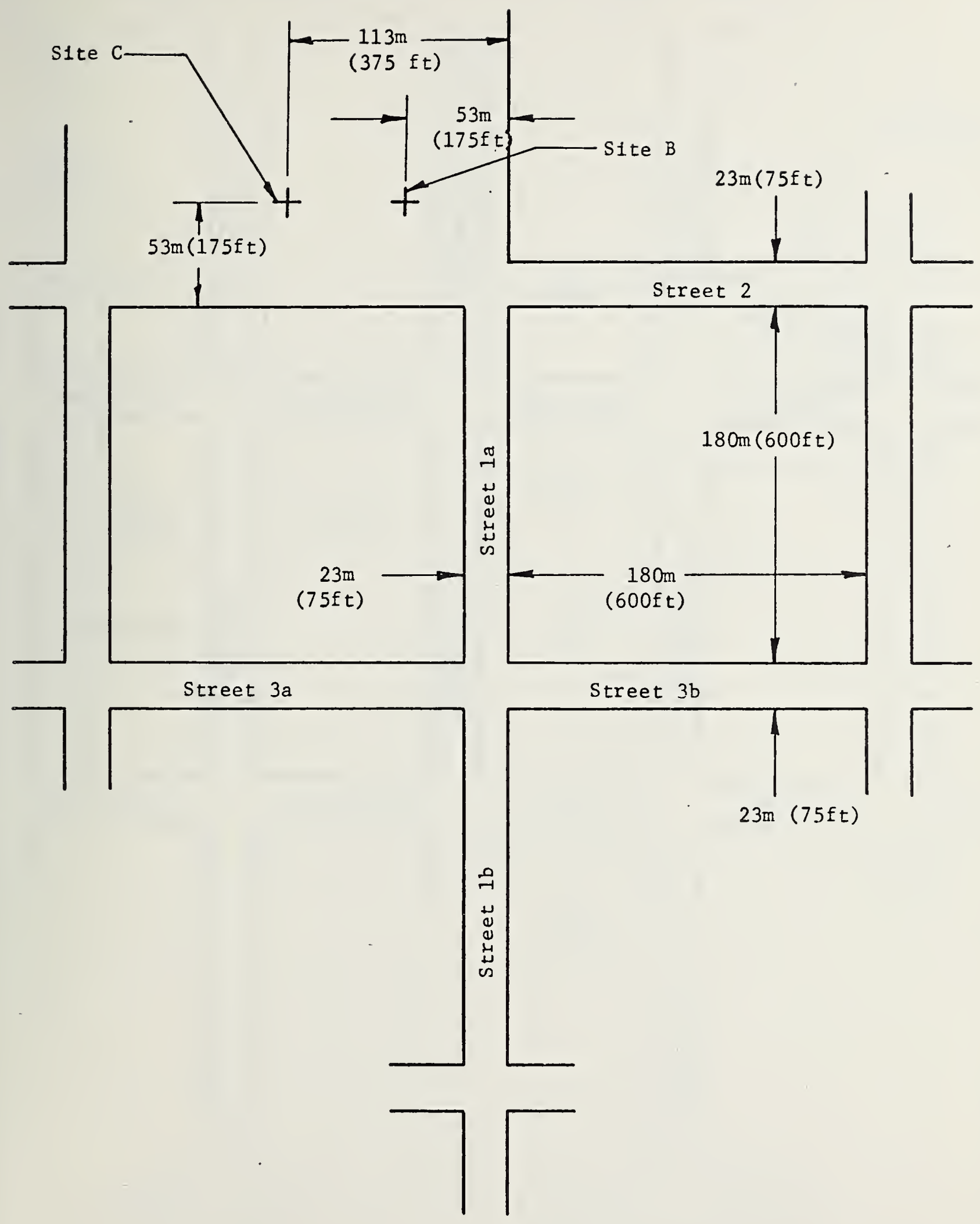

Figure 4: Geometry and Nomenclature for Block Configuration Case I, Sites B and C. 


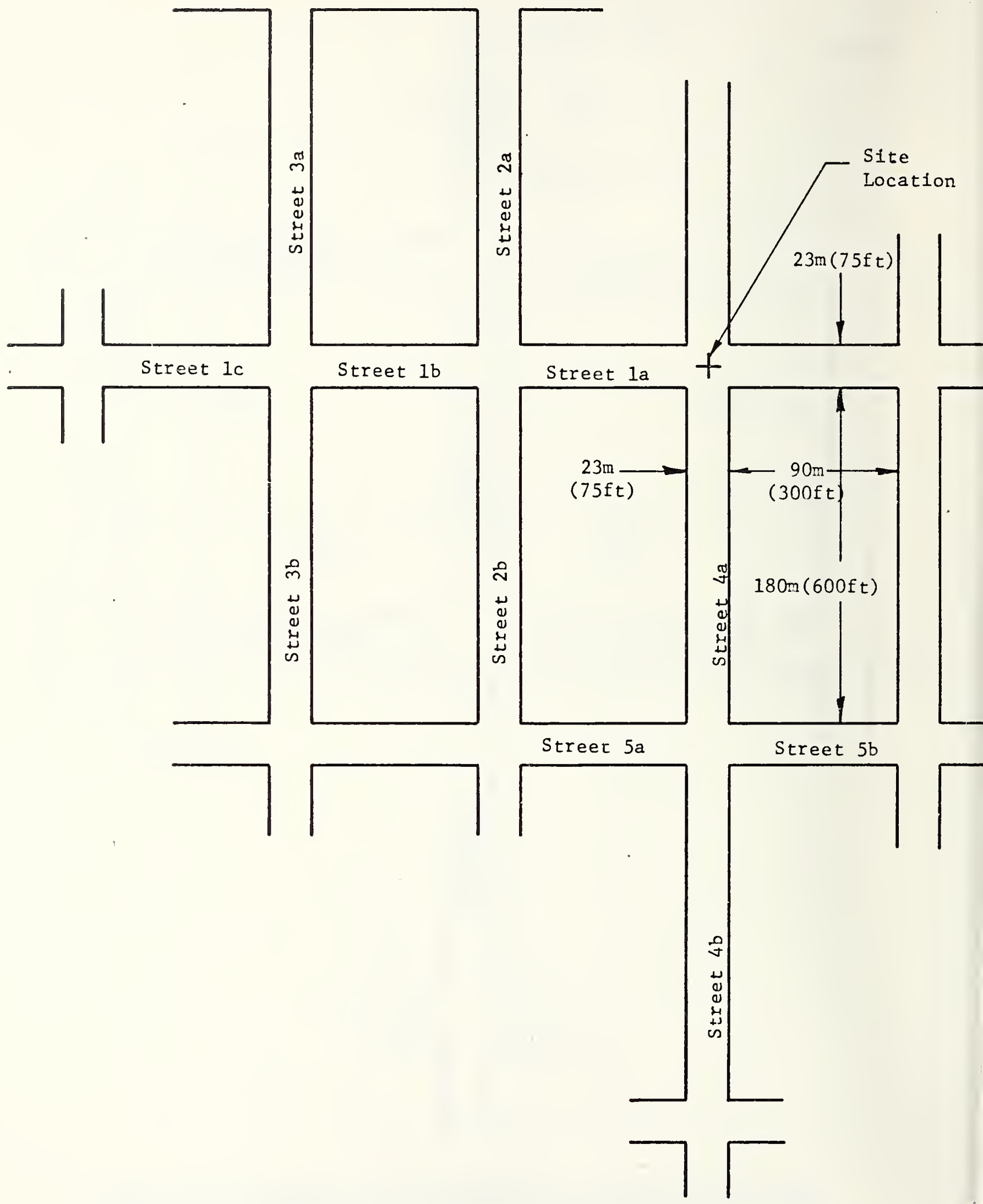

Figure 5: Geometry and Nomenclature for Block Configuration Case II, Site A. 


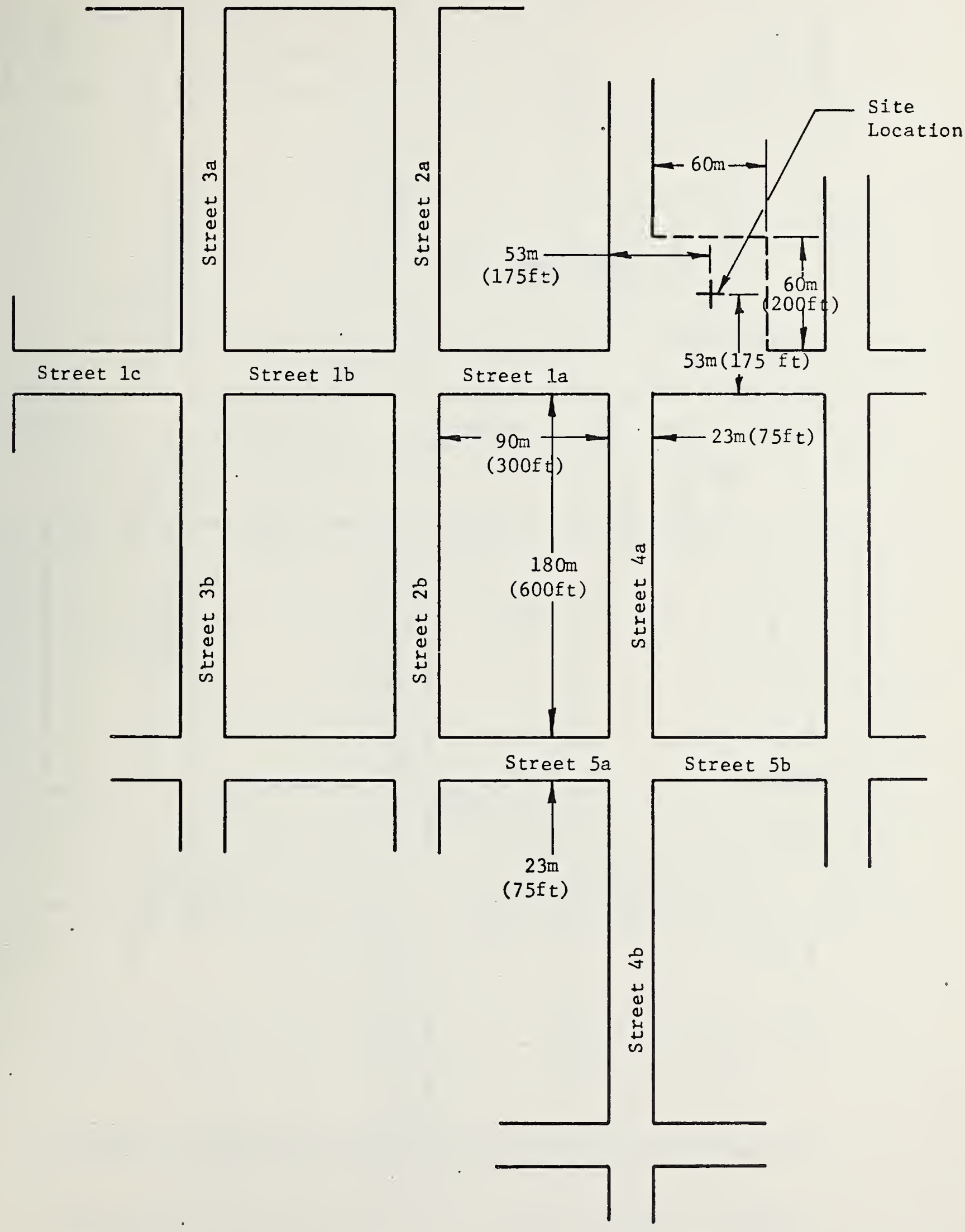

Figure 6: Geometry and Nomenclature.for Block Configuration Case II, S1te B 


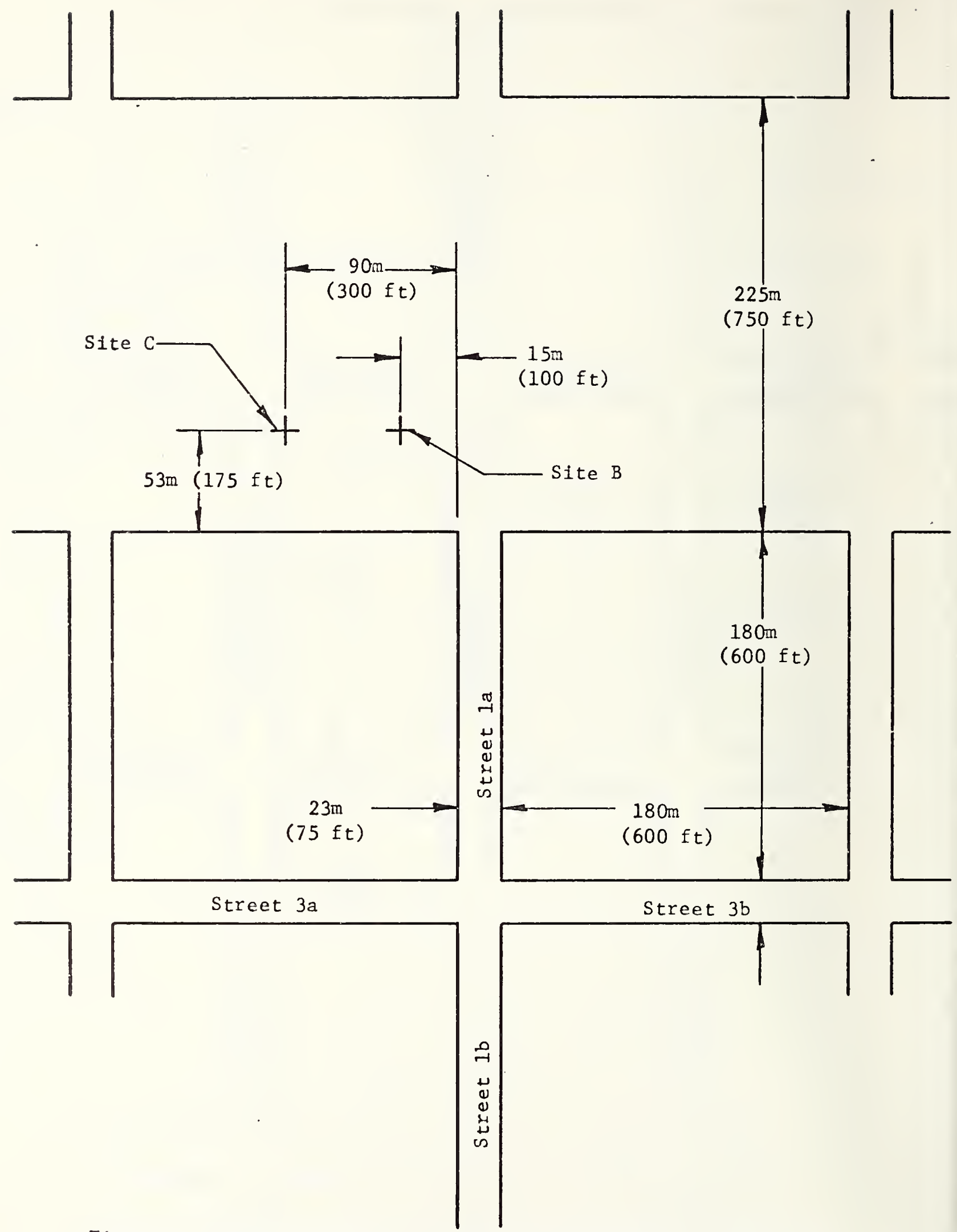

Figure 7: Assumed Geometry for Computed Attenuation Values for Block Configuration Case I, Sites B and C. 


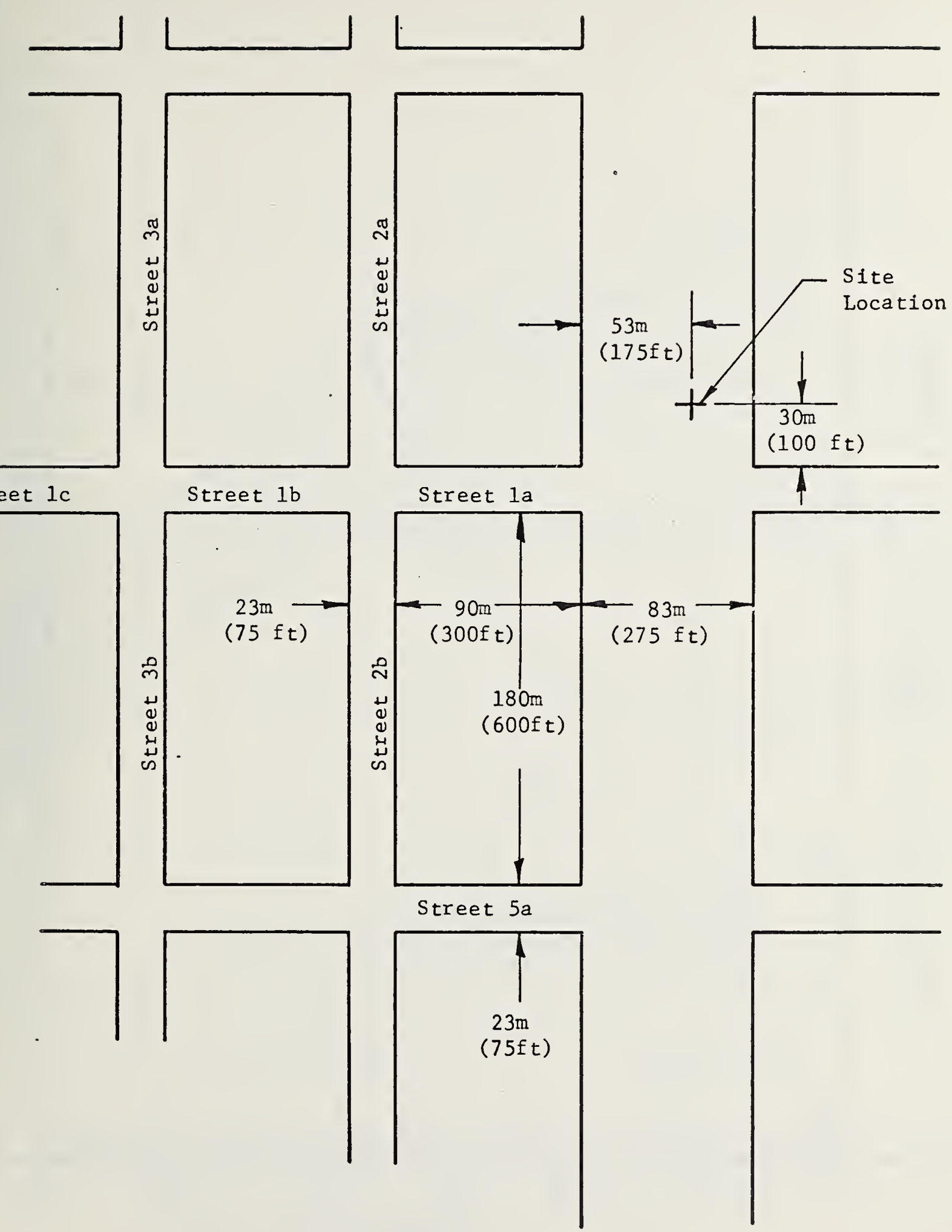

Figure 8: Assumed Geometry for Computed Attenuation Values for Block Configuration Case II, Site B 


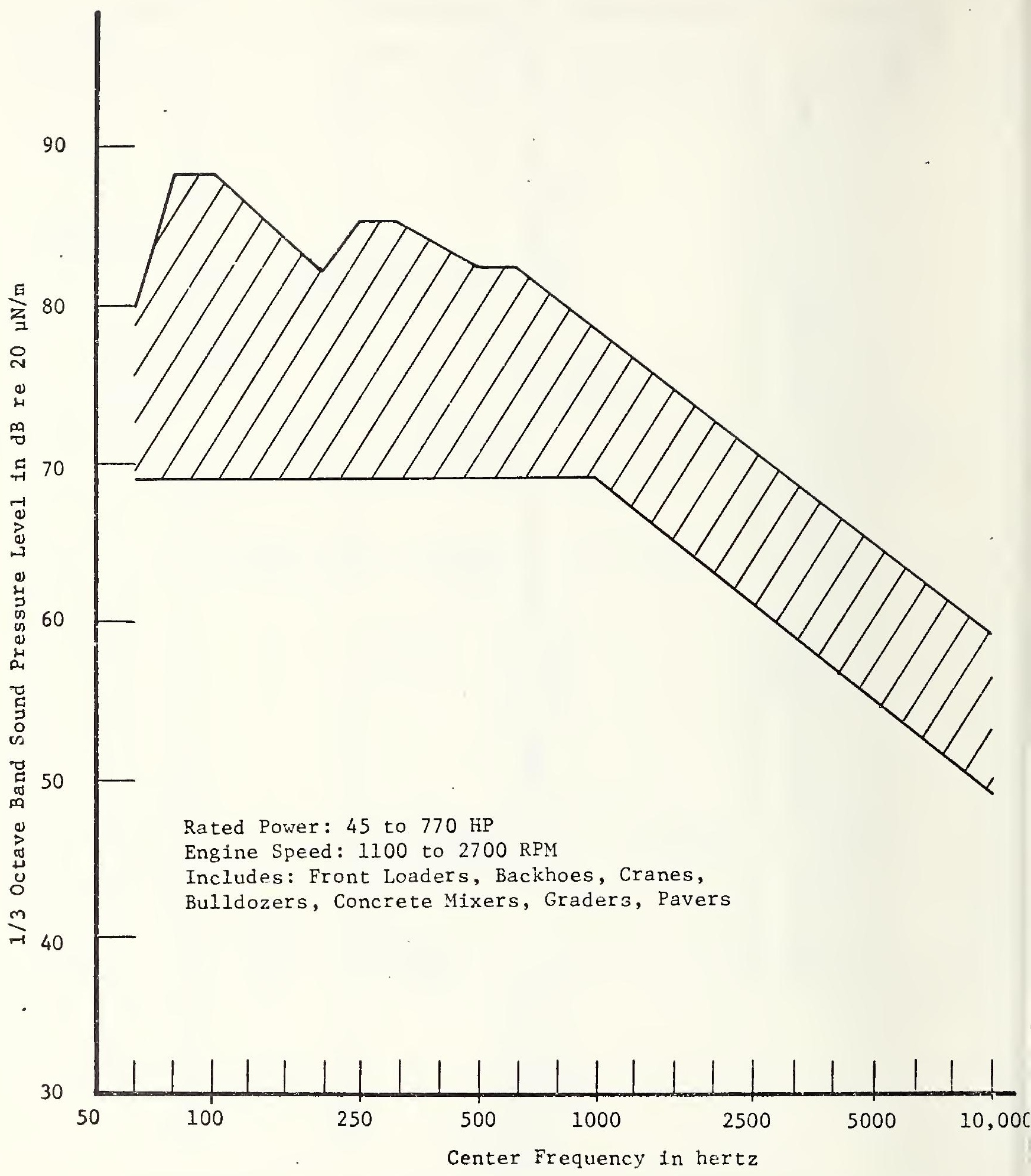

Figure 9: Envelope of Sound Pressure Levels from 23 Diesel-powered Items of Construction Equipment as Measured at $15 \mathrm{~m}$ ( $50 \mathrm{ft}$ ) 


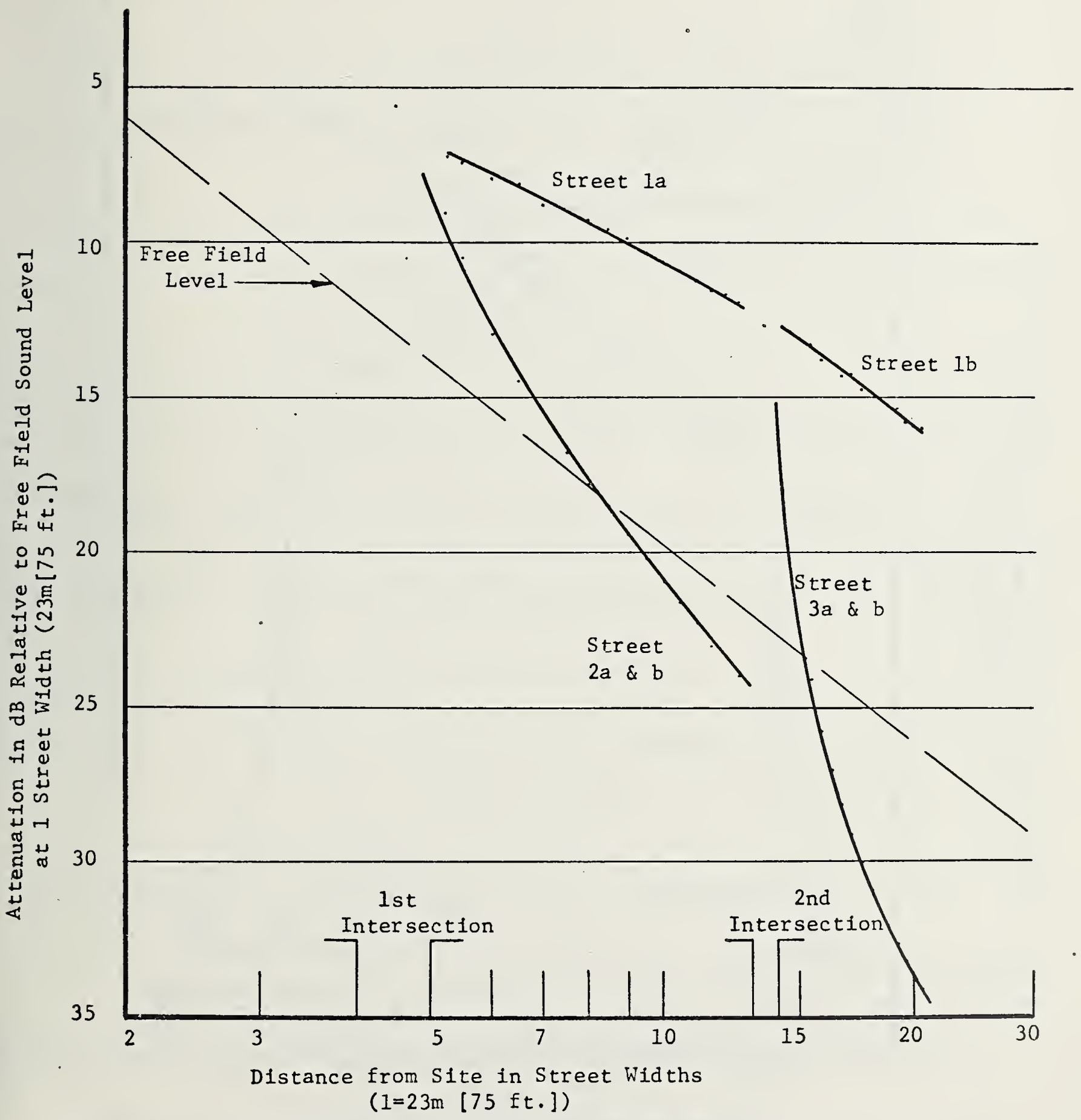

Figure 10: Attenuation as a Function of Distance for Case I, Site A 


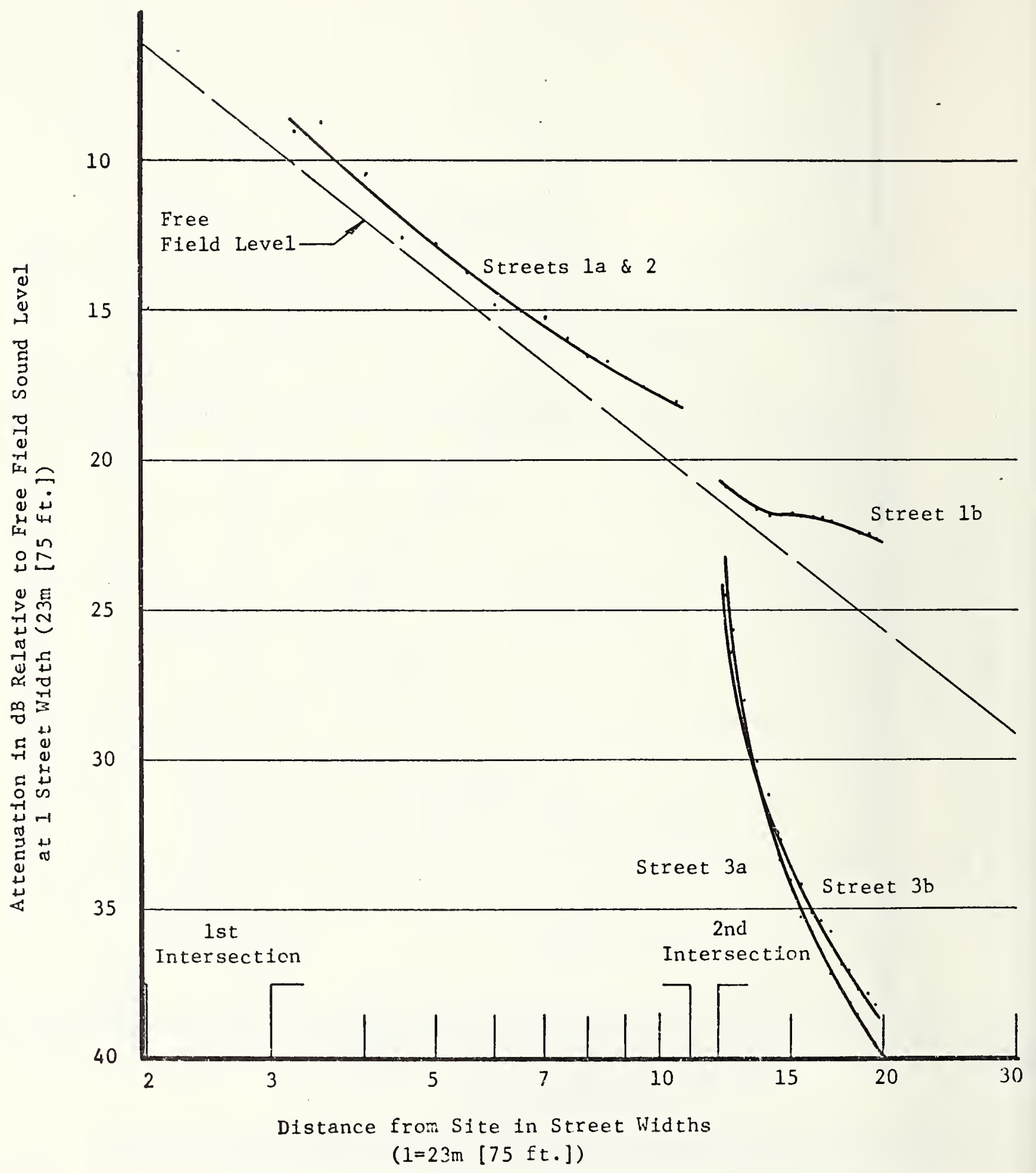

Figure 11: Attenuation as a Function of Distance for Case I, Site B 


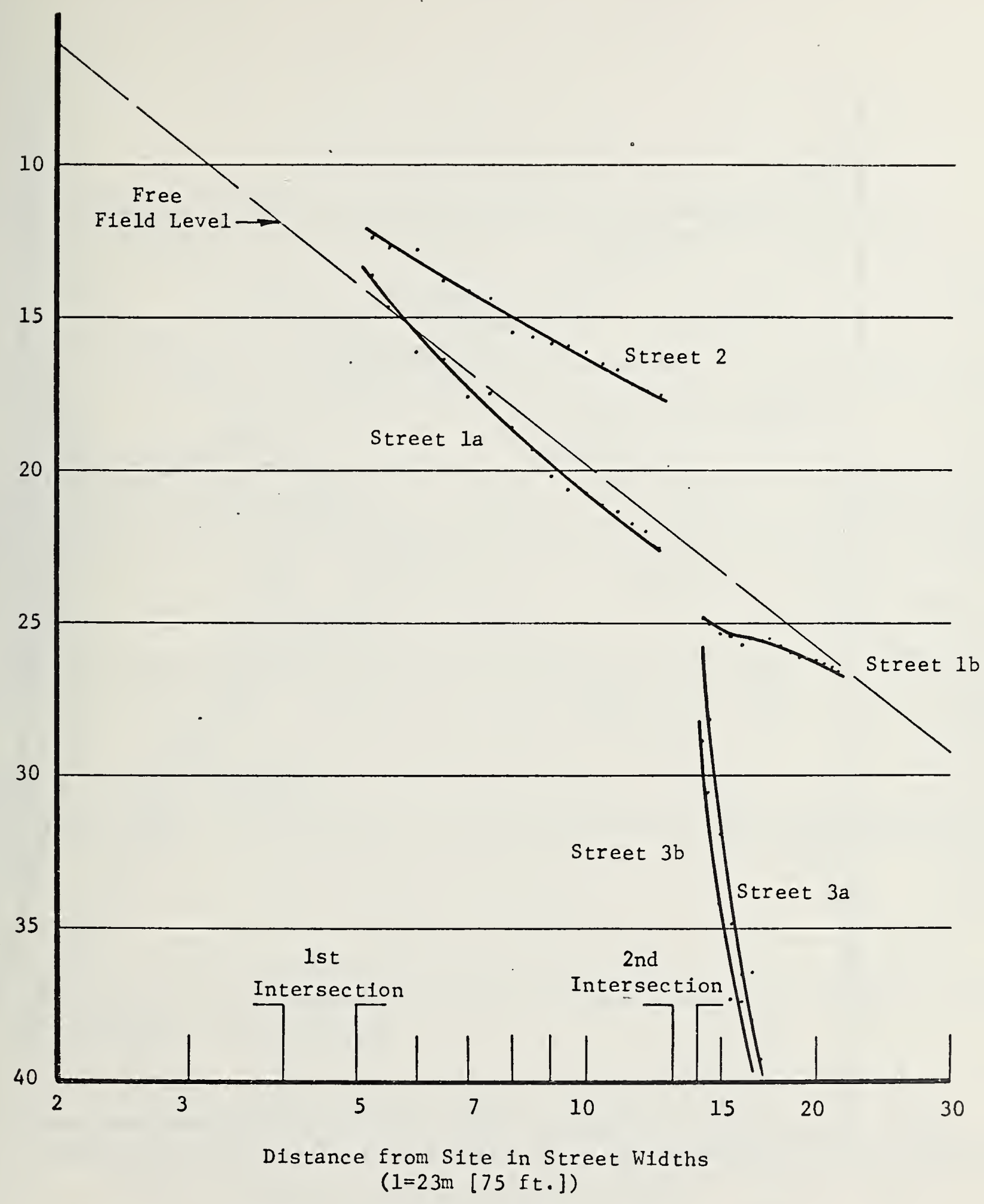

Figure 12: Attenuation as a Function at Distance for Case I, Site C. 


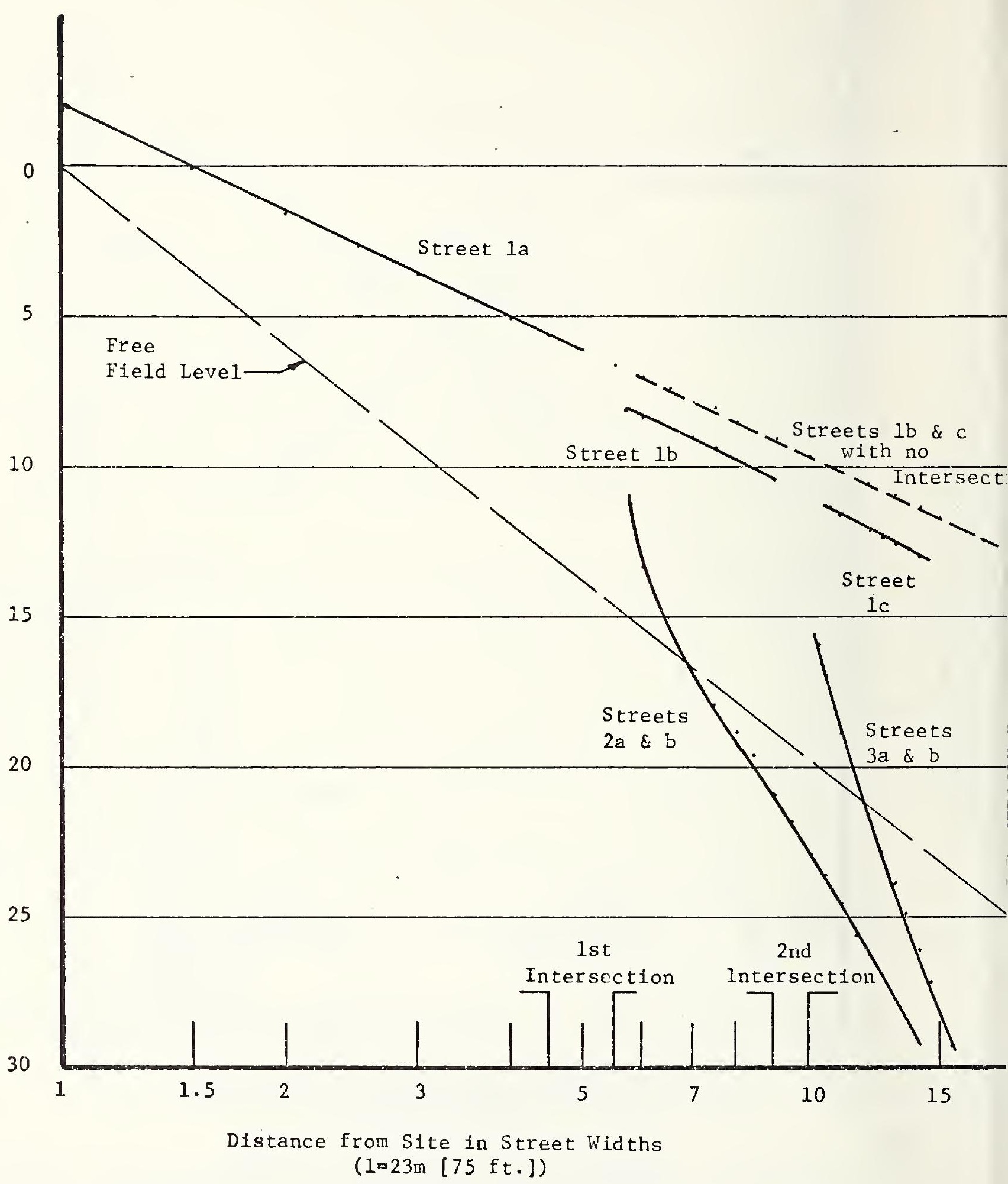

Figure 13: Attenuation as a Function of Distance for Case II, Site A, Streets 1, 2, and 3 . 


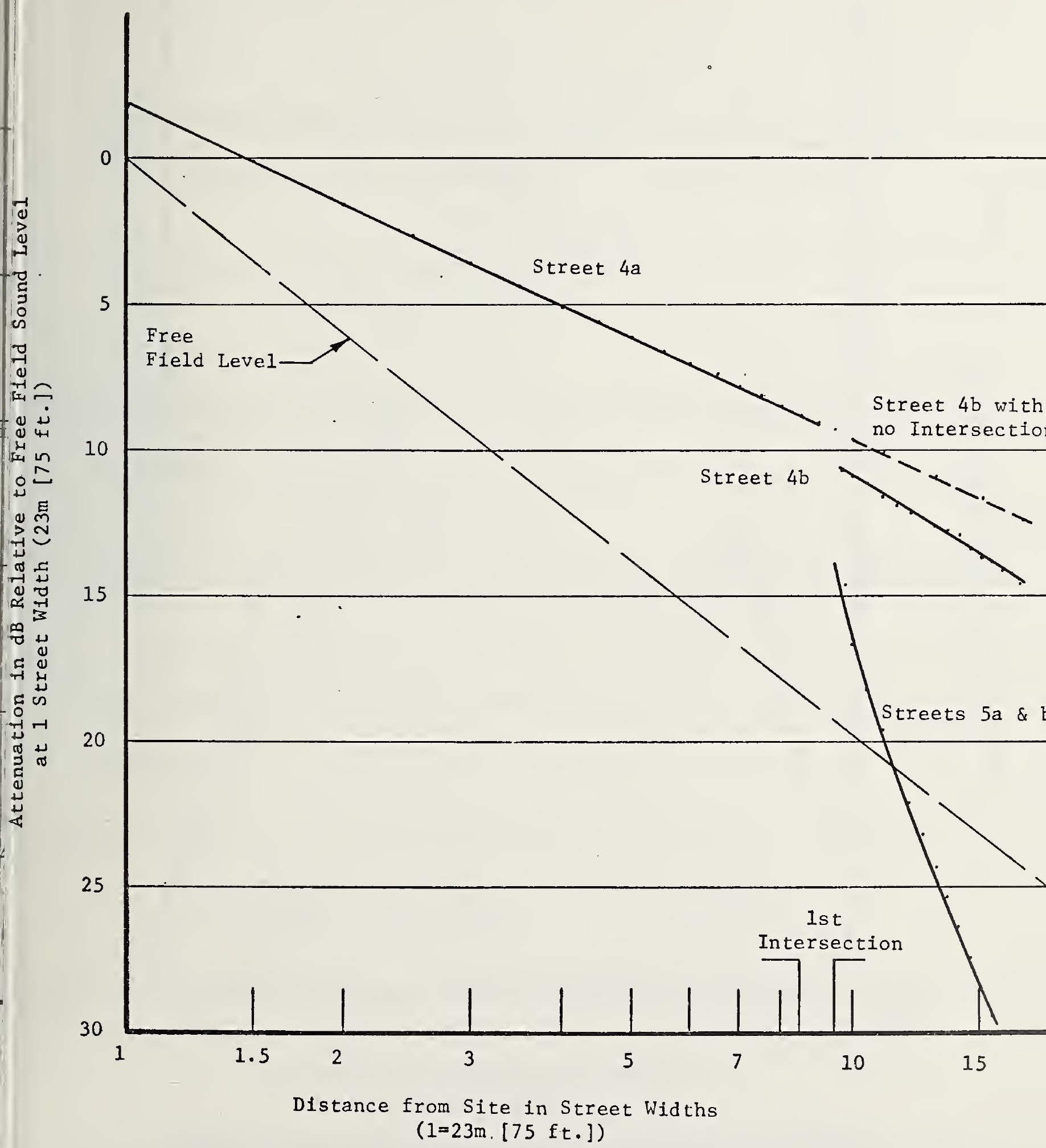

Figure 14: Attenuation as a Function of Distance for Case II, Site A, Streets 4 and 5 . 
Free
Field Level $\longrightarrow$
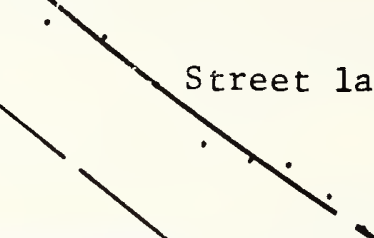

15
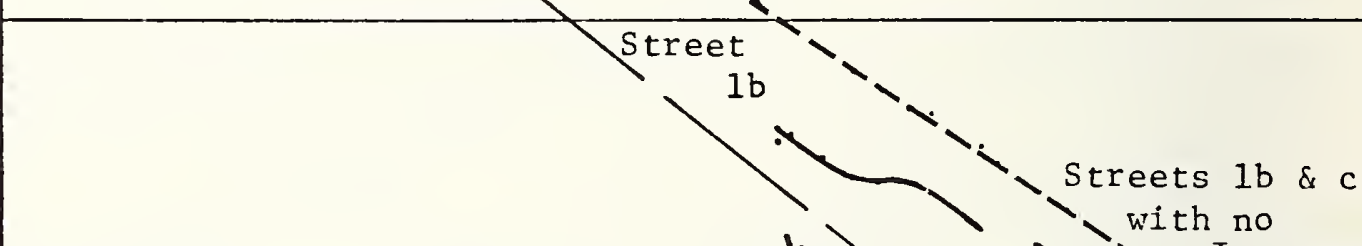

20

0

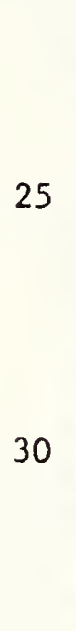

35

30

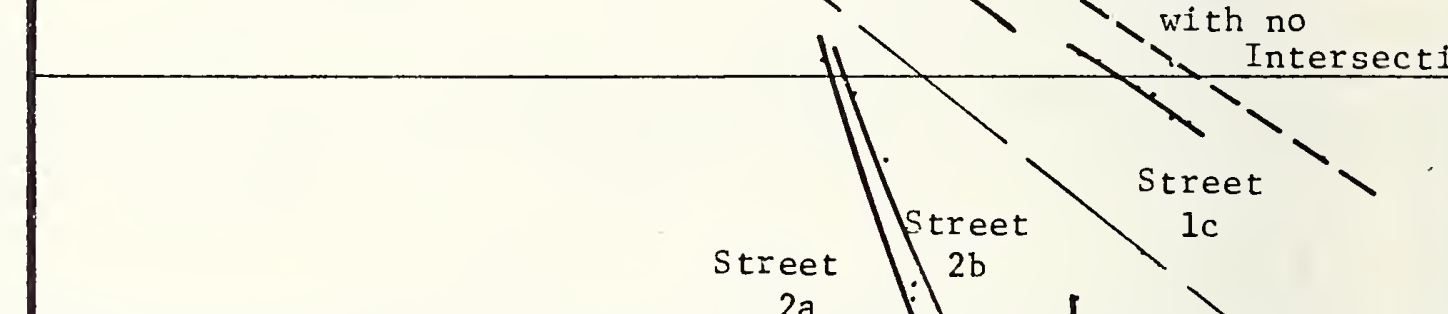

$1 s t$

$2 a$

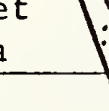

40

2

3

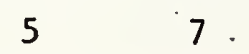

7.

10

15

20

Distance from Site in Street Widths $(1=23 \mathrm{~m}[75 \mathrm{ft.}])$

Figure 15: Attenuation as a Function of Distance for Case II, Site B, Streets 1, 2, and 3 . 


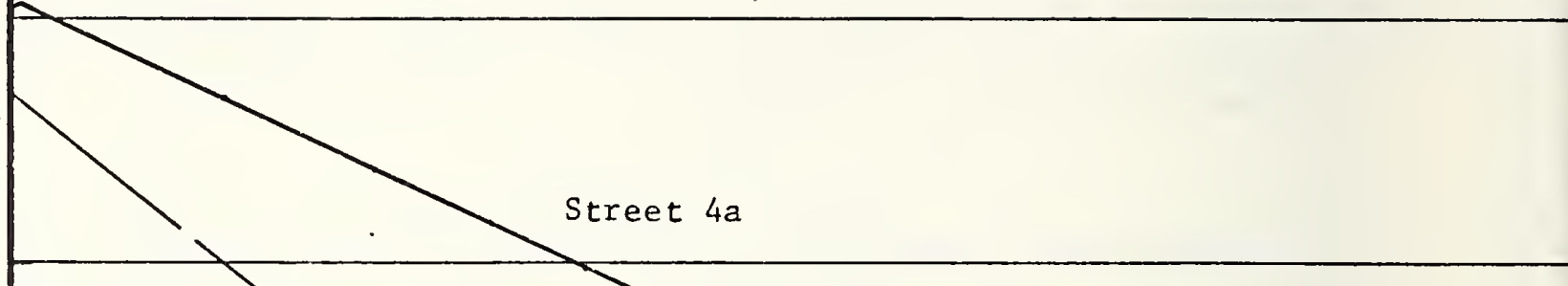

70

Free Field

Level-

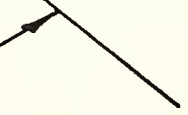

65

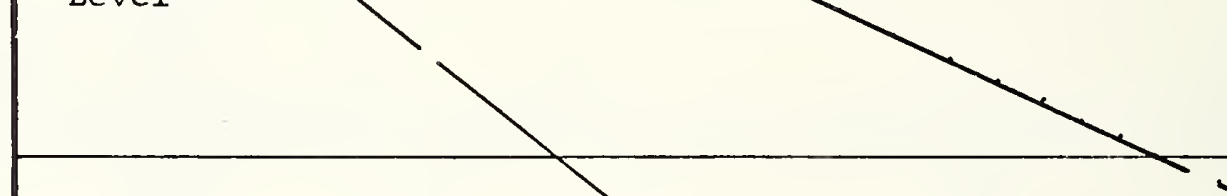

60

55

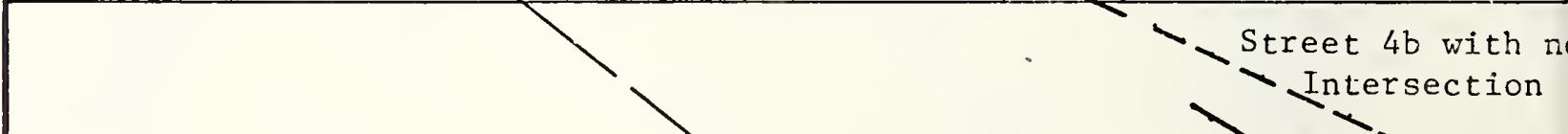

65

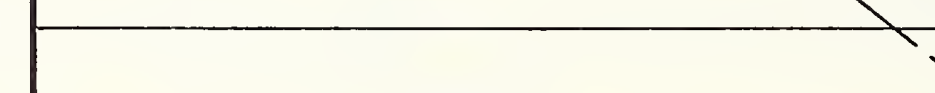

treet $4 b$
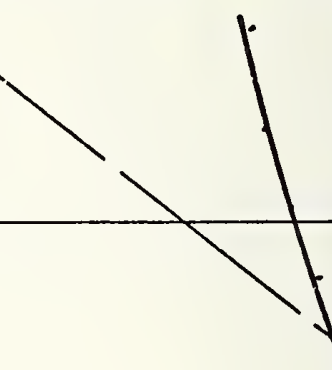

Streets $5 a \&$

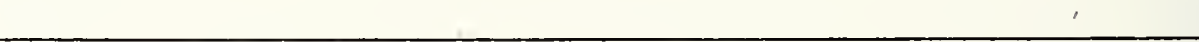

lst

Intersection

50

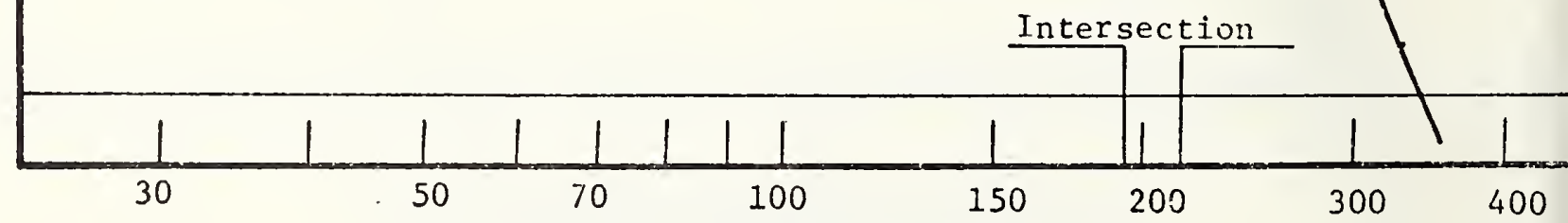

Distance from Site in meters

Figure 17: A-We1ghted Sound Levels as a Function of Distance for Case II, Site A, Streets 4 and 5 for a Source Level of $82 \mathrm{~dB}$ at $15 \mathrm{~m}$ (50 $\mathrm{ft}$ ) 


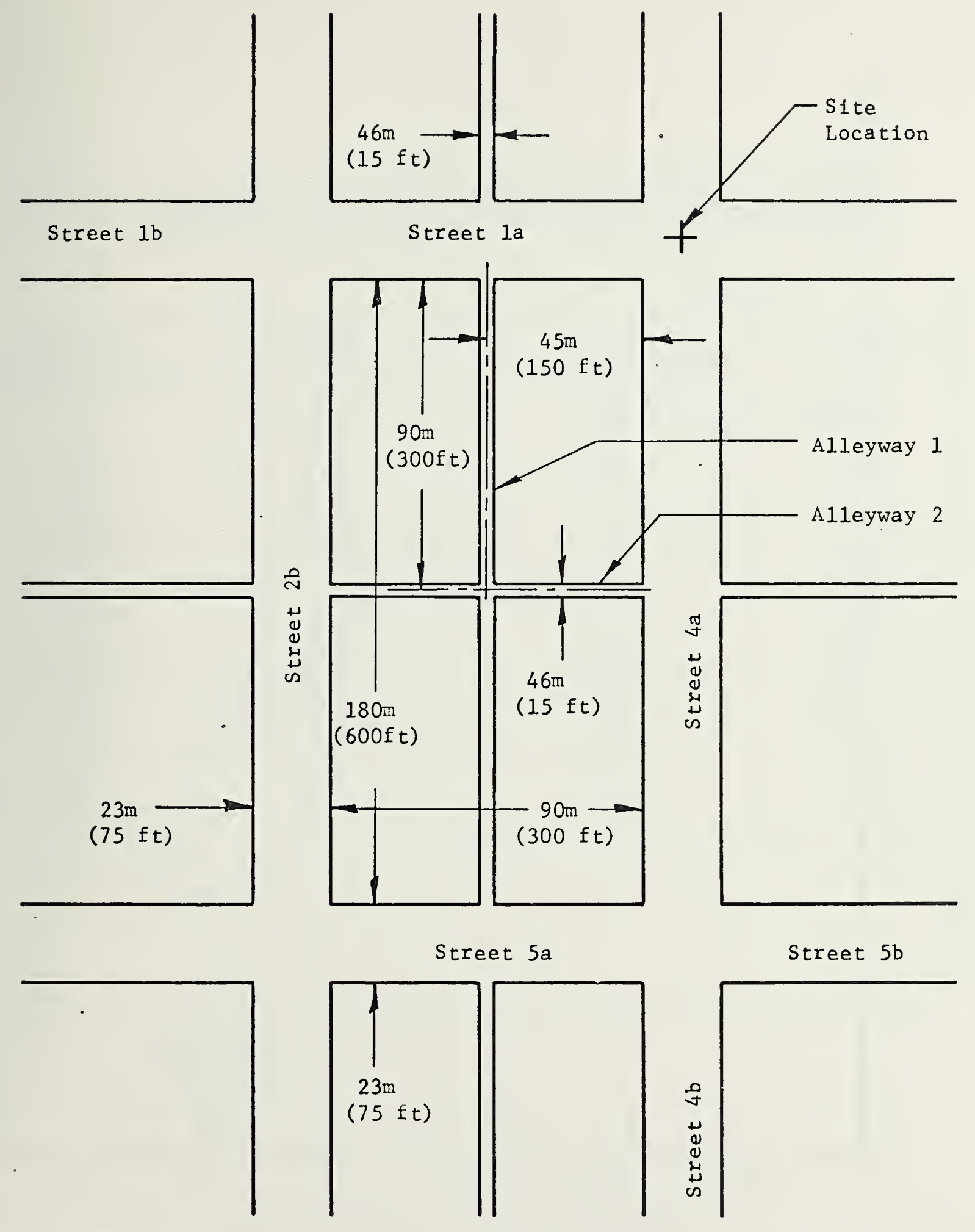

Figure 18: Geometry and Nomenclature for Assessment of Sound Propagation Into Blocks Along Alleyways - Case II, Site A 


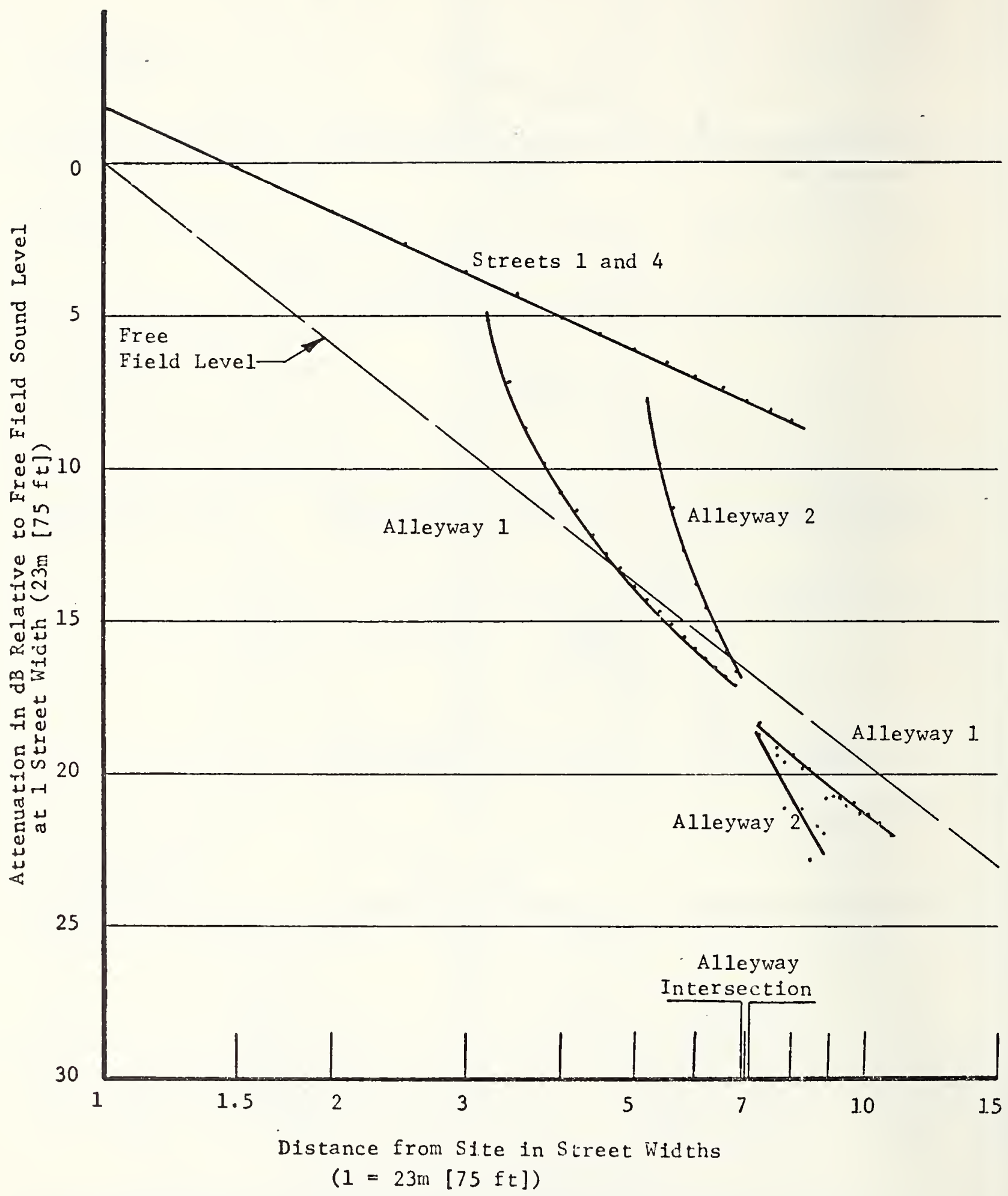

Figure 19: Attenuation as a Function of Distance for Case II, Site A, Alleyways 1 and 2 (strictly valid for only octave band sound pressure levels greater than $500 \mathrm{~Hz}$.) 
Table 1: Case I, Site A, Street 1 - Attenuation Relative to Free Field Sound Level At 1 Street Width (75 ft.) as a Function of Distance From the Site.

Street la Distance
(Street Widths)

Attenuation

$(\mathrm{dB})$

7.3

7.5

8.0

8.2

8.8

9.0

9.4

9.6

10.0

10.4

10.7

11.0

11.3

11.6

11.7

12.0
Street $1 \mathrm{~b}$

$\begin{array}{cc}\text { Distance } & \text { Attenuation } \\ \text { (Street Widths) } & (\mathrm{dB})\end{array}$

14.2

14.5

15.0

15.5

16.0

16.5

17.0

17.5

18.0

18.5

19.0

19.5

20.0

20.5

21.0

21.5
12.7

12.9

13.2

13.4

13.8

13.9

14.4

14.3

14.8

14.8

15.1

15.3

15.3

15.8

15.9

16.0 
Table 2 : Case I, Site A, Streets 2 and 3 - Attenuation Relative to Free Field Sound Level at 1 Street Width ( $75 \mathrm{ft}$. ) as a Function of Distance into Side Street

\section{Distance (Street Widths)}

.25

.5

1.0

1.5

2.0

2.5

3.0

3.5

4.0

4.5

5.0

5.5

6.0

6.5

7.0

7.5
Streets $2 a \& b$

Attenuation

(dB)

9.1

10.5

13.0

14.5

15.5

16.8

17.8

18.5

19.5

20.2

21.0

21.6

22.3

23.0

23.4

24.0
Streets $3 a \& b$ Attenuation $(\mathrm{dB})$ 18.0

19.9

22.7

24.1

25.8

27.0

28.2

29.1

30.0

30.9

31.5

32.0

32.6

33.2

33.7

34.1 
Table 3: Case I, Site B, Streets 1 and 2 - Attenuation Relative to Free Field Sound Level at 1 Street Width $(75 \mathrm{ft}$ ) as a Function of Distance from the Site as Measured Along the Street

Street la \& 2 Distance (Street Widths Attenuation (dB)

9.0

8.7

10.5

12.6

12.7

13.7

14.8

15.0

15.2

15.9

16.5

16.7

17.2

17.5

17.8

18.0

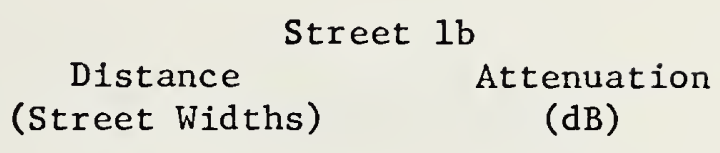

12.6

12.8

13.3

13.8

14.3

14.8

15.3

15.8

16.3

16.8

17.3

17.8

18.3

18.8

19.3

19.8
20.9

21.0

21.3

21.6

21.8

21.8

21.7

21.8

21.8

21.8

22.0

22.2

22.3

22.4

22.4

22.6 
Table 4 : Case I, Site B, Street 3 - Attenuation Relative to Free Field Sound Level at 1 Street Width $(75 \mathrm{ft}$ ) as a Function of Distance into the Side Street

Distance
(Street Wid ths)
.25
.5
1.0
1.5
2.0
2.5
3.0
3.5
4.0
4.5
5.0
5.5
6.0
6.5
7.0
7.5

Street $3 a$ Attenuation

$(\mathrm{dB})$

23.8

25.7

28.0

30.4

31.8

33.4

33.6

35.3

35.8

36.3

37.2

37.6

38.1

38.5

39.1

39.5
Street 3b

Attenuation

(dB)

24.5

26.4

29.1

30.1

31.2

32.7

34.0

34.1

35.1

35.3

35.7

36.8

37.0

37.7

37.8

38.2 
Table 5: Case I, Site C, Street 1 - Attenuation Relative to Free Field Sound Level at 1 Street Width (75 ft.) as a Function of Distance from the Site as Measured Along the Street

$\begin{array}{cccc}\begin{array}{c}\text { Distance } \\ \text { (Street Widths) }\end{array} & \begin{array}{c}\text { Steet } \\ \text { Attenuation } \\ \text { (dB) }\end{array} & \begin{array}{c}\text { Street } \\ \text { Distance } \\ \text { (Street Widths) }\end{array} & \begin{array}{c}\text { Attenuation } \\ \text { (dB) }\end{array} \\ 2.6 & 13.6 & 12.6 & 24.9 \\ 2.8 & 14.7 & 12.8 & 25.0 \\ 3.3 & 16.2 & 13.3 & 25.3 \\ 3.8 & 16.4 & 13.8 & 25.4 \\ 4.3 & 17.6 & 14.3 & 25.7 \\ 4.8 & 17.5 & 14.8 & 25.5 \\ 5.3 & 18.6 & 15.3 & 25.5 \\ 5.8 & 19.4 & 15.8 & 25.5 \\ 6.3 & 20.2 & 16.3 & 25.7 \\ 6.8 & 20.6 & 16.8 & 25.9 \\ 7.3 & 20.7 & 17.3 & 26.1 \\ 7.8 & 21.1 & 17.8 & 26.1 \\ 8.3 & 21.3 & 18.3 & 26.2 \\ 8.8 & 21.7 & 18.8 & 26.3 \\ 9.3 & 22.0 & 19.3 & 26.4 \\ 9.8 & 22.5 & 19.8 & 26.6 \\ & & & \end{array}$


Table 6: Case I, Site C, Street 2 - Attenuation Relative to Free Field Sound Level at 1 Street Width $(75 \mathrm{ft}$.) as a Function of Distance from the Site as Measured Along the Street

$\begin{array}{cc}\begin{array}{c}\text { Distance } \\ \text { (Street Widths) }\end{array} & \text { Street 2 } \\ & \begin{array}{c}\text { Attenuation } \\ (\mathrm{dB})\end{array} \\ 5.25 & \\ 5.5 & 12.4 \\ 6.0 & 12.7 \\ 6.5 & 12.7 \\ 7.0 & 13.8 \\ 7.5 & 14.1 \\ 8.0 & 14.4 \\ 8.5 & 15.5 \\ 9.0 & 15.6 \\ 9.5 & 15.8 \\ 10.0 & 15.9 \\ 10.5 & 16.1 \\ 11.0 & 16.5 \\ 11.5 & 16.7 \\ 12.0 & 17.2 \\ 12.5 & 17.4 \\ & 17.5\end{array}$


Table 7 : Case I, Site C, Street 3 - Attenuation Relative to Free Field Sound Level at 1 Street Width (75 ft.) as a Function of Distance into the Side Street

$\begin{array}{ccc}\begin{array}{c}\text { Distance } \\ \text { (Street Widths) }\end{array} & \begin{array}{c}\text { Street 3a } \\ \text { Attenuation } \\ (\mathrm{dB})\end{array} & \begin{array}{c}\text { Street } 3 \mathrm{~b} \\ \text { Attenuation } \\ (\mathrm{dB})\end{array} \\ .25 & 26.1 & 28.8 \\ .5 & 28.1 & 30.5 \\ 1.0 & 31.9 & 34.2 \\ 1.5 & 34.9 & 37.3 \\ 2.0 & 36.5 & 37.4 \\ 2.5 & 36.4 & 38.0 \\ 3.0 & 39.3 & 40.6 \\ 3.5 & 41.6 & 42.3 \\ 4.0 & 41.2 & 41.8 \\ 4.5 & 41.5 & 41.9 \\ 5.0 & 43.0 & 43.6 \\ 5.5 & 44.1 & 43.8 \\ 6.0 & 43.2 & 43.8 \\ 6.5 & 44.3 & 44.6 \\ 7.0 & 45.2 & 45.0 \\ 7.5 & 44.7 & 45.3\end{array}$


Table 8: Case II, Site A, Street 1 - Attenuation Relative to Free Field Sound Level at 1 Street Width $(75 \mathrm{ft}$. ) as a Function of Distance from the Site

\begin{tabular}{cccc}
\multicolumn{2}{c}{ Street la } & \multicolumn{2}{c}{ Street $1 \mathrm{~b}$} \\
$\begin{array}{l}\text { Distance } \\
\text { (Street }\end{array}$ & $\begin{array}{c}\text { Attenuation } \\
\text { (dB) }\end{array}$ & $\begin{array}{c}\text { Distance } \\
\text { (Street } \\
\text { Widths) }\end{array}$ & $\begin{array}{c}\text { Attenuation } \\
\text { (dB) }\end{array}$ \\
& & & \\
.75 & -2.8 & 5.7 & 8.2 \\
1.0 & -1.9 & 6.0 & 8.4 \\
1.5 & 0.1 & 6.5 & 8.7 \\
2.0 & 1.6 & 7.0 & 9.0 \\
2.5 & 2.7 & 7.5 & 9.4 \\
3.0 & 3.6 & 8.0 & 9.8 \\
3.5 & 4.4 & 8.5 & 10.1 \\
4.0 & 5.1 & 9.0 & 10.5 \\
4.5 & 5.6 & &
\end{tabular}

Street $1 c$ Distance Attenuation (Street Widths)

$(\mathrm{dB})$

10.7

11.0

11.5

12.0

12.5

13.0

13.5

14.0
11.3

11.6

11.8

12.1

12.4

12.6

12.7

13.0 
Table 9: Case II, Site A, Streets 2 and 3 - Attenuation Relative to Free Field Sound Level at 1 Street Width ( $75 \mathrm{ft}$. ) as a Function of Distance into the Side Street

Streets $2 a$ and $b$

Distance

(Street Widths)

.3

.5

1.0

1.5

2.0

2.5

3.0

3.5

4.0

4.5

5.0

5.5

6.0

6.5

7.0

7.5

\section{Attenuation}

(dB)

11.2

13.4

15.0

16.8

17.9

18.8

19.7

20.9

21.8

23.0

23.6

24.6

25.6

26.2

26.9

27.7

Streets $3 a$ and $b$

Distance

(Street Wid ths)
Attenuation (dB)

15.9

17.0

18.9

20.3

21.6

22.8

23.8

24.9

26.1

27.2

28.3

29.4

30.5

31.5

32.3

33.1 


$$
\begin{aligned}
& \text { Table 10: Case II, Site A, Street } 4 \text { - Attenuation Relative to } \\
& \text { Free Field Sound Level at } 1 \text { Street Width }(75 \mathrm{ft.} \text { ) } \\
& \text { as a Function of Distance from the Site }
\end{aligned}
$$

$\begin{array}{cccc}\begin{array}{c}\text { Distance } \\ \text { (Street Widths) }\end{array} & \begin{array}{c}\text { Street } 4 \mathrm{attenuation} \\ (\mathrm{dB})\end{array} & \begin{array}{c}\text { Distance } \\ \text { (Street Widths) }\end{array} & \begin{array}{c}\text { Attenuation } \\ \text { (dB) }\end{array} \\ .75 & -2.8 & 9.7 & 10.7 \\ 1.0 & -1.9 & 10.0 & 10.9 \\ 1.5 & .1 & 10.5 & 11.2 \\ 2.0 & 1.6 & 11.0 & 11.6 \\ 2.5 & 2.7 & 11.5 & 11.9 \\ 3.0 & 3.6 & 12.0 & 12.1 \\ 3.5 & 4.4 & 12.5 & 12.3 \\ 4.0 & 5.1 & 13.0 & 12.6 \\ 4.5 & 5.6 & 13.5 & 12.7 \\ 5.0 & 6.1 & 14.0 & 12.9 \\ 5.5 & 6.6 & 14.5 & 13.4 \\ 6.0 & 7.0 & 15.0 & 13.6 \\ 6.5 & 7.4 & 15.5 & 13.8 \\ 7.0 & 7.8 & 16.0 & 14.1 \\ 7.5 & 8.1 & 16.5 & 14.2 \\ & & 17.0 & 14.6\end{array}$


Table 11: Case II, Site A, Street 5 - Attenuation Relative to Free Field Sound Level at 1 Street Width (75 ft.) as a Function of Distance into the Side Street

Streets $5 \mathrm{a}$ and $\mathrm{b}$

Distance
(Street Widths)
.3
.5
1.0
1.5
2.0
2.5
3.0
3.5
4.0

Attenuation

(dB)

14.7

16.6

18.2

19.6

21.0

22.1

23.2

24.3

25.3 
Table 12: Case II, Site B, Street 1 - Attenuation Ralative to Free Field Sound Level at 1 Street Width $(75 \mathrm{ft}$.) as a Function of Distance From the Site as Measured Along the Street

\begin{tabular}{|c|c|c|c|c|c|}
\hline \multicolumn{2}{|c|}{ Street $1 \mathrm{a}$} & \multicolumn{2}{|c|}{ Street $1 \mathrm{~b}$} & \multicolumn{2}{|c|}{ Street $1 c$} \\
\hline $\begin{array}{l}\text { Distance } \\
\text { (Street } \\
\text { Widths) }\end{array}$ & $\begin{array}{l}\text { Attenuation } \\
\text { (dB) }\end{array}$ & $\begin{array}{l}\text { Distance } \\
\text { (Street } \\
\text { Widths) }\end{array}$ & $\begin{array}{l}\text { Attenuation } \\
(\mathrm{dB})\end{array}$ & $\begin{array}{l}\text { Distance } \\
\text { (Street } \\
\text { Widths) }\end{array}$ & $\begin{array}{l}\text { Attenuation } \\
\text { (dB) }\end{array}$ \\
\hline 2.6 & 7.7 & 7.6 & 17.4 & 12.6 & 19.4 \\
\hline 2.8 & 7.5 & 7.8 & 17.2 & 12.8 & 19.5 \\
\hline 3.3 & 8.8 & 8.3 & 17.7 & 13.3 & 19.7 \\
\hline 3.8 & 10.6 & 8.8 & 18.2 & 13.8 & 20.0 \\
\hline 4.3 & 10.8 & 9.3 & 18.2 & 14.3 & 20.2 \\
\hline 4.8 & 11.8 & 9.8 & 18.1 & 14.8 & 20.4 \\
\hline 5.3 & 13.0 & 10.3 & 18.4 & 15.3 & 20.8 \\
\hline 5.8 & 13.3 & 10.8 & 18.7 & 15.8 & 20.9 \\
\hline
\end{tabular}


Table 13: Case II, Site B, Streets 2 and 3 - Attenuation Relative to Free Field Sound Level at 1 Street Width (75 ft.) as a Function of Distance into the Side Street

$\begin{array}{ccccc}\begin{array}{c}\text { Distance } \\ \text { (Street Widths) }\end{array} & \begin{array}{c}\text { Street 2a } \\ \text { Attenuation } \\ (\mathrm{dB})\end{array} & \begin{array}{c}\text { Street 2b } \\ \text { Attenuation } \\ \text { (dB) }\end{array} & \begin{array}{c}\text { Street 3a } \\ \text { Attenuation } \\ \text { (dB) }\end{array} & \begin{array}{c}\text { Street 3b } \\ \text { Attenuation } \\ \text { (dB) }\end{array} \\ .3 & 19.1 & 17.4 & & 24.0 \\ .5 & 19.5 & 19.7 & 24.4 & 26.4 \\ 1.0 & 21.4 & 20.3 & 27.5 & 28.1 \\ 1.5 & 23.2 & 21.6 & 29.0 & 31.1 \\ 2.0 & 24.3 & 24.1 & 30.7 & 32.7 \\ 2.5 & 26.1 & 25.4 & 32.6 & 33.7 \\ 3.0 & 27.7 & 25.2 & 34.0 & 35.1 \\ 3.5 & 28.3 & 26.5 & 34.5 & 36.7 \\ 4.0 & 29.5 & 27.3 & 35.7 & 36.5 \\ 4.5 & 30.1 & 28.2 & 36.2 & 37.7 \\ 5.0 & 31.2 & 28.6 & 37.1 & 38.3 \\ 5.5 & 32.2 & 29.9 & 37.9 & 38.7 \\ 6.0 & 32.6 & 30.4 & 37.9 & 39.5 \\ 6.5 & 33.3 & 30.9 & 38.6 & 39.9 \\ 7.0 & 33.6 & 31.2 & 39.1 & 40.7 \\ 7.5 & 34.4 & 31.8 & 39.4 & 40.7\end{array}$


Table 16: Case II, Site B, Street 4 - Attenuation Relative to Free Field Sound Level at I Street Width (75 ft.) as a Function of Distance from the Site as Measured Along the Street

$\begin{array}{cccc}\begin{array}{c}\text { Distance } \\ \text { (Street Widths) }\end{array} & \begin{array}{c}\text { Street } \\ \text { Attenuation } \\ (\mathrm{dB})\end{array} & \begin{array}{c}\text { Sistance } \\ \text { (Street Widths) }\end{array} & \begin{array}{c}4 \mathrm{~b} \\ \text { Attenuation } \\ (\mathrm{dB})\end{array} \\ 2.6 & 7.7 & 11.6 & \\ 2.8 & 7.5 & 11.8 & 18.9 \\ 3.3 & 8.8 & 12.3 & 19.0 \\ 3.8 & 10.6 & 12.8 & 19.3 \\ 4.3 & 10.8 & 13.3 & 19.8 \\ 4.8 & 11.8 & 13.8 & 19.9 \\ 5.3 & 13.0 & 14.3 & 20.1 \\ 5.8 & 13.3 & 14.8 & 20.3 \\ 6.3 & 13.4 & 15.3 & 20.4 \\ 6.8 & 14.0 & 15.8 & 20.5 \\ 7.3 & 14.7 & 16.3 & 20.6 \\ 7.8 & 15.1 & 16.8 & 20.9 \\ 8.3 & 15.5 & 17.3 & 21.1 \\ 8.8 & 16.0 & 17.8 & 21.4 \\ 9.3 & 16.4 & 18.3 & 21.5 \\ 9.8 & 16.7 & 18.8 & 21.6 \\ & & & 21.9\end{array}$


Table 15: Case II, Site B, Street 5 - Attenuation Relative to Free Field Sound Level at 1 Street Width (75 ft.) as a Function of Distance into the Side Street

$\begin{array}{ccc}\begin{array}{c}\text { Distance } \\ \text { (Street Widths) }\end{array} & \begin{array}{c}\text { Street 5a } \\ \text { Attenuation } \\ (\mathrm{dB})\end{array} & \begin{array}{c}\text { Street } 5 \mathrm{~b} \\ \text { Attenuation } \\ (\mathrm{dB})\end{array} \\ .3 & 22.9 & \\ .5 & 24.1 & 22.0 \\ 1.0 & 27.0 & 23.4 \\ 1.5 & 27.9 & 26.0 \\ 2.0 & 29.5 & 28.3 \\ 2.5 & 31.3 & 30.1 \\ 3.0 & 32.7 & 31.7 \\ 3.5 & 33.3 & 32.5 \\ & & 34.4\end{array}$



U.S. DEPT. OF COMM.

BIBLIOGRAPHIC DATA SHEET
1. PUBLICATION OR REPORT NO.

NBSIR 79-1594

TIFLE AND SUBTITLE

Propagation of Urban Construction Site Noise Along

Street Corridors

5: Publication Date

May 8, 1978

6. Performing Organization Code

8. Performing Organ. Report No.

Paul R. Donavan and J. Craig Wyvill

9. PERFORMING CRGANIZATION NAME AND ADDRESS

NATIONAL BUREAU OF STANDARDS

DEPARTMENT OF COMMERCE

WASHINGTON, DC 20234

10. Project/Task/Work Unit No.

11. Contract/Grant No.

EPA-IAG-D6-0755

12. SPONSORING ORGAN:ZATION NAME AND COMPLETE ADDRESS (Street, City, State, ZIP)

13. Type of Report \& Period Covered

Office of Noise Abatement and Control

U.S. Environmental Protection Agency

Fina1

1921 Jefferson Davis Highway

Arlington, VA 20460

15. SUPPLEMENTARY NOTES

Document describes a computer program; SF-185, FIPS Software Summary, is attached.

16. ABSTRACT (A 200-word or less factual summary of most sigrificant information. If document includes a significant bibliography or literature survey, mention it here.)

An existing urban sound propagation model has been applied to the specific problem of estimating the propagation of noise from urban construction sites along street corridors. Discussion summarizes the development of the propagation model and computer programs used to estimate sound propagation. The propagation model has been applied to five different construction site orientations resulting from two city blcck configurations. For each of the site orientations, the estimated values of attenuation versus distance in the streets surrounding individual sites are presented. Assuming the sound level at the construction site is known, the procedure to be used to determine sound levels in the surrounding streets is also provided.

17. KEY WORDS (six to twolve entries; alphabetical order; capitalize only the first letter of the first koy word unleas a proper natne; separated by semicolons)

Construction site noise; Environmental noise; Noise, Sound Propagation; Urban environment; Urban noise

\section{AVAILABILITY \\ [ Unlimited}

- QXX For Official Distribution. Do Ifot Release to NTIS

Order From Sup. of Doc., U.S. Government Printing Office, Washington, DC 20402, SD Stock No. SN003.003-

Order From National Technical Information Service (NTIS), Springficld, VA. $2216 !$

\begin{tabular}{|l|c|}
\hline $\begin{array}{l}\text { 19. SECURITY CLASS } \\
\text { (THIS REPORT) }\end{array}$ & $\begin{array}{c}\text { 21. NO. OF } \\
\text { PRINTED PAGES } \\
\text { UNCLASSIFIED }\end{array}$ \\
\hline $\begin{array}{l}\text { 20. SECURITY CLASS } \\
\text { (THIS PAGE) }\end{array}$ & 23 \\
UNCLASSIFIED & \\
\hline
\end{tabular}


